\title{
Possible climatic implications of high-altitude black carbon emissions
}

\author{
Gaurav Govardhan ${ }^{1}$, Sreedharan Krishnakumari Satheesh ${ }^{1,2}$, Ravi Nanjundiah ${ }^{1,2}$, \\ Krishnaswamy Krishna Moorthy ${ }^{1}$, and Surendran Suresh Babu ${ }^{3}$ \\ ${ }^{1}$ Centre for Atmospheric and Oceanic Sciences, Indian Institute of Science, Bangalore, India \\ ${ }^{2}$ Divecha Centre for Climate Change, Indian Institute of Science, Bangalore, India \\ ${ }^{3}$ Space Physics Laboratory, Vikram Sarabhai Space Centre, Kerala, India \\ Correspondence to: Gaurav Govardhan (govardhan.gaurav@gmail.com)
}

Received: 1 February 2017 - Discussion started: 13 February 2017

Revised: 10 July 2017 - Accepted: 11 July 2017 - Published: 10 August 2017

\begin{abstract}
On account of its strong absorption of solar and terrestrial radiation, black carbon (BC) aerosol is known to impact large-scale systems, such as the Asian monsoon and the Himalayan glaciers, in addition to affecting the thermal structure of the lower atmosphere. While most studies focus on the near-surface abundance and impacts of BC, our study examines the implications of sharp and confined layers of high BC concentration (called elevated BC layers) at altitudes more than $4 \mathrm{~km}$ over the Indian region using the online regional chemistry transport model (WRF-Chem) simulations. These elevated BC layers were revealed in the recent in situ measurements using high-altitude balloons carried out on 17 March 2010, 8 January 2011 and 25 April 2011. Our study demonstrates that high-flying aircraft (with emissions from the regionally fine-tuned MACCity inventory) are the most likely cause of these elevated BC layers. Furthermore, we show that such aircraft-emitted BC can be transported to upper tropospheric or lower stratospheric heights $(\sim 17 \mathrm{~km})$ aided by the strong monsoonal convection occurring over the region, which is known to overshoot the tropical tropopause, leading to the injection of tropospheric air mass (along with its constituent aerosols) into the stratosphere. We show observational evidence for such an intrusion of tropospheric $\mathrm{BC}$ into the stratosphere over the Indian region using extinction coefficient and particle depolarisation ratio data from CALIOP Lidar on-board the CALIPSO satellite. We hypothesise that such intrusions of BC into the lower stratosphere and its consequent longer residence time in the stratosphere have significant implications for stratospheric ozone, espe-
\end{abstract}

cially considering the already reported ozone-depleting potential of BC.

\section{Introduction}

The important role played by atmospheric aerosol particles in global and regional climate forcing is becoming increasingly accepted. The global mean net radiative forcing (including rapid adjustments) by aerosol is estimated to be -0.9 [-1.9 to -0.1$] \mathrm{W} \mathrm{m}^{-2}$ (Boucher et al., 2013) after accounting for the negative forcing by most of the aerosol species (sulfate, nitrate, sea salts, etc.), the strong positive forcing by black carbon (BC), which absorbs solar radiation over a wide spectral band, and to a lesser extent dust and organics. $\mathrm{BC}$, a fine particulate, is formed as a result of incomplete combustion of fossil fuels, biofuels and biomass (Kuhlbusch et al., 1996; Ramanathan and Carmichael, 2008; Bond et al., 2013). As a strong absorber of solar and terrestrial radiation, BC heats up the atmosphere (Petzold and Schönlinner, 2004; Ramanathan et al., 2007). The global mean radiative forcing by $\mathrm{BC}$ is estimated as $+0.4(+0.05$ to +0.8$) \mathrm{W} \mathrm{m}^{-2}$, which is around one-fourth of the global mean $\mathrm{CO}_{2}$ radiative forcing (Boucher et al., 2013). Several earlier studies have shown that atmospheric heating by a layer of aerosol with high BC abundance is capable of perturbing large-scale atmospheric phenomena, such as the Asian monsoon system, and can also affect the hydrological cycle (Chakraborty et al., 2004; Ramanathan et al., 2005; Lau et al., 2006). Also on account of its absorbing nature, $\mathrm{BC}$, if deposited on snow, would 
exert snow-albedo forcing resulting from the darkening of snow and could accelerate the melting of glaciers (Lau et al., 2010; Qian et al., 2011; Yasunari et al., 2010; Nair et al., 2013; Gautam et al., 2013). Furthermore, when BC particles are located above highly reflective surfaces (such as snow or clouds), their absorption efficiency is amplified (Haywood and Shine, 1995; Satheesh and Moorthy, 2005; Chand et al., 2009; Nair et al., 2013). This heating can give rise to local elevated dry convection, which can further lift the BC particles to higher levels of the atmosphere (de Laat et al., 2012). The atmospheric heating by $\mathrm{BC}$ would be more severe at higher altitudes due to reduced air density at these altitudes, and this could amplify the heating effect. High-altitude heating due to $\mathrm{BC}$ can also lead to reduced cloud cover at these elevated altitudes (Ackerman et al., 2000). Additionally, atmospheric heating at higher altitudes can give rise to the local stability scenario described below, which can affect convection and consequently impact precipitation (Fan et al., 2008). Such lifted BC and other pollutants, upon interaction with the strong convection (e.g. occurring during the monsoonal period over the southern Asian region), can be lifted to even higher heights (Andreae et al., 2001; Fromm et al., 2005; Randel et al., 2010; Vernier et al., 2011) with the potential to be lifted even beyond the tropopause and intrude into the stratosphere under favourable upper tropospheric conditions. For such cross-tropopause transport over the tropics, the tropical tropopause layer (TTL) assumes importance. The TTL is the region between the top of the major convective towers and the cold point. While forming an interface between the two dynamically different regimes, the TTL acts as an entry point to the tropical stratosphere (Fueglistaler et al., 2009). Using radiosonde measurements, Sunilkumar et al. (2013) have reported a thinning of the TTL and a reduction in the temperature lapse rate (TLR) within the TTL, which favour such cross-tropopause transport over the Indian region during the monsoon season. A recent study by Das et al. (2016) reports the cross-tropopause transport of air mass over the Indian region during the cyclone "Nilam". Once the particles enter the stratosphere, they reside for a longer period of time due to the inherent stability of the stratosphere and the absence of strong removal mechanisms. Moreover, they can take part in heterogeneous chemical reactions in the stratosphere.

The aforementioned effects together highlight the significance of knowing the vertical distribution of $\mathrm{BC}$, especially over regions of strong convection (such as the Indian subcontinent, especially during the pre-monsoon and monsoon months). With this backdrop, a few studies have examined the vertical distribution of aerosols (extinction coefficient values and/or BC mass concentration values) over the Indian region using multiple observational platforms, such as ground-based (Satheesh et al., 2006), airborne or space-based lidar (Satheesh et al., 2008; Prijith et al., 2016), instrumented aircraft (Moorthy et al., 2004; Babu et al., 2008, 2010; Nair et al., 2016) and tethered and high-altitude balloons (Babu et al., 2011). Carrying out such observations for the first time over India, Moorthy et al. (2004) noticed an exponential decrease in $\mathrm{BC}$ concentration within the boundary layer and a steady value above it over an urban station (Hyderabad) in south-central India during February 2004. Examining the vertical profile of aerosols over Bangalore (an urban station in the southern part of India) using a groundbased micro-pulse lidar, Satheesh et al. (2006) have reported morning-time (nighttime) vertical lifting (confinement) of aerosols during summer days. Carrying out airborne measurements of BC and absorption coefficients over several stations across India, Babu et al. $(2008,2010)$ and Nair et al. (2016) have reported a near-steady vertical distribution up to an altitude of $3 \mathrm{~km}$ above the ground with isolated peaks of higher $\mathrm{BC}$ concentration and absorption coefficients during the pre-monsoon period above most of the landmass. Synthesising multi-platform measurements, Satheesh et al. (2008) have revealed the existence of elevated aerosol layers in the middle troposphere $(4-5 \mathrm{~km})$. They have shown that these elevated aerosol layers caused atmospheric heating, which exhibited a meridional gradient that varied in vertical extent and amplitude from the northern Indian Ocean to Central India, during the pre-monsoon season. Using hydrogen-inflated zero-pressure balloon measurements for the first time in India, Babu et al. (2011) revealed strikingly sharp and confined layers of $\mathrm{BC}$ at altitudes of 4.5 and $8 \mathrm{~km}$ over Hyderabad during the pre-monsoon season of 2010. They also reported a large decrease in the environmental lapse rate associated with these peaks using concurrent measurements aboard the same balloon. Analysing multi-year satellite (CALIPSO) data, Prijith et al. (2016) have not only confirmed the existence of high-altitude aerosol layers and their meridional gradient in the vertical extent during pre-monsoon periods over the Indian region, but have also shown that mineral dust aerosol forms the dominant component of this layer. Kompalli et al. (2016) have reported springtime enhancement in columnar aerosol optical depth (AOD) and BC over Hanle, a western trans-Himalayan high-altitude observational location $(4.5 \mathrm{~km}$ amsl). They attributed this enhancement to summertime lifting of aerosols over the region west to southwest of Hanle and their subsequent long-range transport. All the above studies clearly highlight the existence of highaltitude aerosol layers (with a significant amount of BC) over the southern Asian region during the pre-monsoon periods. Such strong absorbing aerosol layers can perturb the southern Asian regional monsoonal system and affect the glacial coverage of the southern Asian region. Thus, it becomes imperative to understand the dynamics of these regional highaltitude aerosol layers and investigate the exact causes behind their occurrence.

In this study, we revisit the three high-altitude balloon measurements of BC made during the years 2010 and 2011 (in different seasons) over Hyderabad (the only location in India where such balloon ascents could be made) and investigate the potential causes behind the existence of such con- 
fined BC layers using a regional chemistry transport model. The balloon experiments, the model and simulation details are described Sect. 2, and in Sect. 3 we discuss the results. The possible climatic implications of such high-altitude BC layers are discussed in Sect. 4. The conclusions are presented in Sect. 5.

\section{Methods}

\subsection{High-altitude measurements of $\mathrm{BC}$}

The vertical profiles of $\mathrm{BC}$ used in this study have been obtained using an Aethalometer (model AE42; Magee Scientific, USA) aboard high-altitude zero-pressure balloons launched from the National Balloon Facility at Hyderabad, $\left(17.48^{\circ} \mathrm{N}, 78.47^{\circ} \mathrm{E}, 557 \mathrm{ma.m} . s .1.\right)$ during three ascents made on 17 March 2010 and 8 January and 25 April 2011. The first and third flights corresponded to pre-monsoon conditions, while the second flight occurred in winter. The details of the experimental set-up, calibration, data collection and analysis are available in Babu et al. (2011) and only a brief account is given here. The $109755 \mathrm{~m}^{3}$ zero-pressure balloon was made of $25 \mathrm{~mm}$ linear low-density polyethylene film and was capable of carrying $\sim 350 \mathrm{~kg}$ of payload up to a ceiling altitude of $\sim 35 \mathrm{~km}$. The mass concentration of equivalent black carbon (EBC; Petzold et al., 2013) was measured using an Aethalometer, which estimates the mass concentration of EBC by measuring the change in the transmittance of a quartz filter to $880 \mathrm{~nm}$ of light upon the deposition of aerosol. The value of the effective mass absorption cross section (MAC) used in these measurements is $16 \mathrm{~m}^{2} \mathrm{~g}^{-1}$ (Hansen, 1996, 2005). The effective MAC includes the amplification of absorption due to multiple scattering on the filter fiber matrix and the decrease due to shadowing. The Aethalometer was configured for volumetric flow with an external pump providing a flow rate of $14 \mathrm{~L}$ per minute (LPM) at ground and operated at a time base of $5 \mathrm{~s}$. The data from the Aethalometer was telemetered down along with the GPS coordinates. A few studies have reported uncertainties in Aethalometer-estimated EBC (for e.g. Weingartner et al., 2003; Arnott et al., 2005; Sheridan et al., 2005; Corrigan et al., 2006). Following these suggestions from the reports, we have used an amplification factor of 1.9 and an $R$ factor (shadowing effect) of 0.88 in this study. Nevertheless, when the aerosols are aged or mixed with other species, as they would be away from direct emissions, the shadowing effect would be negligible (Weingartner et al., 2003). In addition to $\mathrm{BC}$, dust also absorbs shortwave radiation, but the mass absorption cross section (MAC) for dust is 2 to 3 orders of magnitude lower than that for BC at $880 \mathrm{~nm}$ (Hansen, 2005). Hence if the mass of dust is substantially higher than EBC, then only the same optical absorption will be produced at $880 \mathrm{~nm}$. Thus, under normal conditions, the effects of dust on measured EBC mass concentrations would be negligible.
In addition to the Aethalometer, each ascent also carried other payloads, such as a GPS receiver, meteorological sensors for temperature and RH, telemetry and telecommand systems. The entire payload was tested using a thermovacuum facility to ensure consistent operations up to $\sim 9 \mathrm{~km}$ of altitude $\left(250 \mathrm{hPa}\right.$ pressure level and $\left.\sim-40^{\circ} \mathrm{C}\right)$. Beyond this altitude, the ambient pressure drops too low to provide sufficient flow to the Aethalometer. The telecommand system was used to switch off the instrument for the higher altitudes and switch it on again at this altitude during the descent phase. A gondola carrying the payloads was attached to the balloon using a parachute, which was deployed in the descent phase and enabled the safe recovery of the payloads for reuse. Ballast cans attached to the gondola ensured a slow and steady ascent of $\sim 2.6 \mathrm{~m} \mathrm{~s}^{-1}$, while the descent speed was controlled by the parachute, as the ballast cans were detached after the balloon rose to the free tropospheric altitude. The scientific data along with the housekeeping data were collected during the ascent and descent phases and were continuously telemetered to the ground in addition to being stored on-board. The total flight duration was about 3 to $4 \mathrm{~h}$ for each flight and the spatial ground spread of the flight path was within a $50 \mathrm{~km}$ radius of the launch site. The data were analysed (following details in Babu et al., 2011) and the profiles obtained were smoothed using a running mean filter. The same protocols were followed for all the flights.

\subsection{Model and simulation details}

We used the regional chemistry transport model, WRFChem, to simulate the observed vertical profiles of $\mathrm{BC}$ and to understand the causes behind the sharp layers of $\mathrm{BC}$ at elevated altitudes. The WRF-Chem model was employed with a horizontal grid spacing of $2 \mathrm{~km}$ with 70 vertical levels and $100 \mathrm{~m}$ of vertical resolution around the layers at 4-6, 8-9 and $10-11 \mathrm{~km}$. Such a high vertical resolution was chosen to resolve the BC peaks accurately when simulated by the model. Of the remaining levels, 10 are located within the boundary layer $(0-2 \mathrm{~km})$. A relatively coarser resolution $(500 \mathrm{~m})$ is set for the remaining altitude bands, i.e. $2-4,6-8$ and $9-10 \mathrm{~km}$. Beyond $11 \mathrm{~km}$, the vertical resolution is set to be $1 \mathrm{~km}$. The details about the vertical levels in the model simulations can be found in Table 1 . The model domain $\left(75.5-80.5^{\circ} \mathrm{E}, 14.5-\right.$ $20.5^{\circ} \mathrm{N}$ ) centres at Hyderabad and spans around $330 \mathrm{~km}$ in each direction. The simulations were started 16 days prior to the balloon flight days (flight day 1 was 17 March 2010, flight 2 was 8 January 2011 and flight day 3 was 25 April 2011) and were run until the end of the flight day. In these simulations, the convective processes were not parameterised due to the fine grid spacing; cloud microphysical processes were parameterised using the Thompson scheme (Thompson et al., 2004), boundary layer processes were parameterised using the YSU scheme (Hong et al., 2006; Hong, 2010) and the surface processes were modelled using the RUC LSM scheme (Smirnova et al., 1997, 2000). The shortwave radia- 
Table 1. Vertical levels prescribed in WRF-Chem simulations.

\begin{tabular}{lr}
\hline Level index & Altitude $(\mathrm{km})$ \\
\hline $01-10$ & $0-2$ \\
$11-14$ & $2-4$ \\
$15-31$ & $4-6$ \\
$32-37$ & $6-8$ \\
$38-49$ & $8-9$ \\
$50-51$ & $9-10$ \\
$52-59$ & $10-11$ \\
$60-70$ & $11-20$ \\
\hline
\end{tabular}

tion processes were parameterised using the Dudhia scheme (Dudhia, 1989), while the long-wave processes were parameterised using the rapid radiative transfer model (RRTM) (Mlawer et al., 1997). Gas-phase chemistry in these simulations was handled by MOZART mechanisms (Emmons et al., 2010), while the aerosol-phase chemistry was parameterised using the GOCART bulk aerosol scheme (Chin et al., 2002) with the Fast-J scheme for photolysis (Wild et al., 2000).

The model takes into account the following aerosol species: BC1 (hydrophobic), BC2 (hydrophilic), OC1 (hydrophobic), OC2 (hydrophilic), dust (five bins with effective diameters from 0.5 to $8 \mu \mathrm{m}$ ), sea salts (four bins with effective diameters from 0.1 to $7.5 \mu \mathrm{m}$ ) and sulfate. The characteristic conversion e-folding lifetime for $\mathrm{BC}$ from hydrophobic to hydrophilic, i.e. $\mathrm{BC} 1$ to $\mathrm{BC} 2$, is considered to be 2.5 days. More details about the treatment of BC in WRFChem can be found Kumar et al. (2015). The model simulates aerosol transport processes like emissions, advection, diffusion and deposition (dry and wet). The aerosol direct effects are modelled by coupling the aerosol scheme with the radiation scheme. The NCEP FNL (Final) Operational Global Analysis data (interpolated to model resolution) were used for setting up the initial and boundary conditions (updated every $6 \mathrm{~h}$ ) for meteorological variables in the model, while the global chemistry transport model MOZART-4 (Emmons et al., 2010) was used for the creation of initial and boundary conditions for chemistry variables. The near-surface emissions of gas-phase and aerosol-phase species are formulated using the standard emission pre-processor software PREPCHEM-SRC (version 1; Freitas et al., 2011). The RETRO database (Schultz et al., 2007) is used for various greenhouse and precursor gases, EDGAR (Olivier et al., 1996) is used for emissions of $\mathrm{CO}, \mathrm{NO}, \mathrm{NH}_{3}$ and VOCs and the GOCART (Chin et al., 2002) database is used for the emissions OC, BC and $\mathrm{SO}_{2}$ over the region. The necessary modifications in $\mathrm{BC}$ emissions from the GOCART database over this region (Govardhan et al., 2016) have been incorporated. We conducted two sets of simulations for each of the ascents. The first set included only surface emissions (NoACEM is a control run of simulations without the prescription of aircraft emissions of BC) and the second set (ACEM, simulations with the pre- scription of aircraft emissions of BC) included surface and elevated emissions. The details of elevated emissions (BC emissions from aircraft) are discussed in Sect. 2.3.

\subsection{Prescription of aircraft $\mathrm{BC}$ emissions}

To understand the role of $\mathrm{BC}$ emissions from aircraft in the formation of sharp layers of $\mathrm{BC}$ at elevated altitudes, we prescribed aircraft BC emissions from the MACCity global anthropogenic emissions inventory (Lamarque et al., 2010) in the WRF-Chem simulations. The inventory provides aircraft $\mathrm{BC}$ emissions at $0.5^{\circ} \times 0.5^{\circ}$ grids and 23 vertical levels from 0.305 to $13.725 \mathrm{~km}$ with a vertical resolution of $610 \mathrm{~m}$. The vertical profiles of $\mathrm{BC}$ emissions from aircraft averaged over a $1^{\circ} \times 1^{\circ}$ grid box centring Hyderabad (Fig. 1, red line) and over another grid box (Fig. 1, blue line) with the same dimensions just $2^{\circ}$ south-west of the Hyderabad grid box are shown in Fig. 1. The vertical locations of the emission peaks are seen to vary depending on the proximity to an airport (Hyderabad in this case). The near-surface peak could be related to landing and takeoff (LTO) emissions over the airport, while the upper level peaks could be due to the emissions from planes passing over the location without landing.

The basic information this inventory considers includes global aircraft movements, performance characteristics of the different aircraft types, the actual paths of aircraft during their journey and the emission factor for BC. Such a global inventory for aircraft BC emissions inherently has several uncertainties, especially over a region like India, mainly due to uncertainties associated with (a) the amount of total aircraft fuel used across the country by domestic and international fleets, (b) the quality of aircraft fuel, (c) the age of aircraft and hence the degradation in performance, (d) the exact number of civil aircraft flying over the region, (e) the number of military aircraft unaccounted for and (f) the exact routes followed by the aircraft over this region. Additionally, a major source of uncertainty in the estimates of $\mathrm{BC}$ emissions from aircraft is due to uncertainties in the estimations of the emission factor (also known as emission index) for $\mathrm{BC}$ "EI(BC)" for the particular aircraft fuel being used. EI(BC) is the amount of BC emitted $(\mathrm{g})$ per kg of aircraft fuel burnt and it depends on engine type, load conditions and engine conditions. The measurement of EI(BC) by several studies (Herndon et al., 2008; Onasch et al., 2009; Timko et al., 2010) indicates that EI(BC) spans around 4 orders of magnitude. Stettler et al. (2013) discuss and quantify the underestimation of $\mathrm{EI}(\mathrm{BC})$ observed in currently available aircraft BC emissions inventories. In this regard, a previous study (Stettler et al., 2011) has stated: "The First-Order Approximation (FOA3) - currently the standard approach used to estimate particulate matter emissions from aircraft - is compared to measurements and it is shown that there are discrepancies greater than an order of magnitude for $40 \%$ of cases for both organic carbon and black carbon emissions indices". 


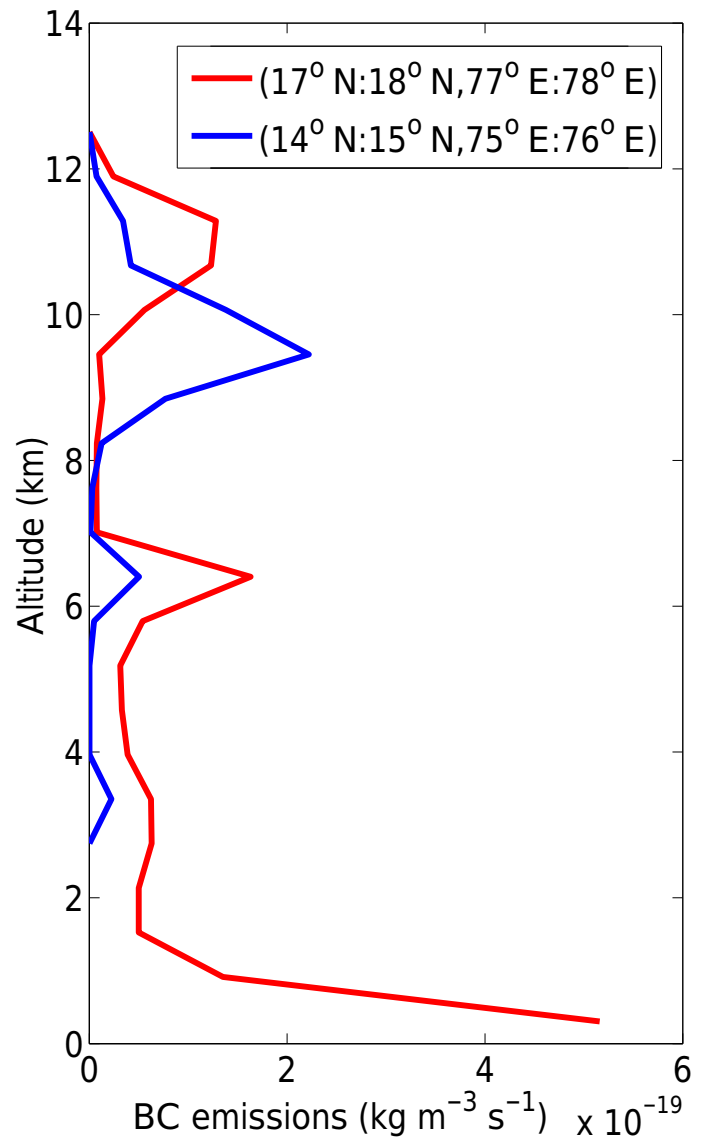

Figure 1. The vertical profile of $\mathrm{BC}$ emissions $\left(\mathrm{kg} \mathrm{m}^{-3} \mathrm{~s}^{-1}\right)$ from aircraft in the MACCity inventory over $1^{\circ} \times 1^{\circ}$ grid boxes (a) centred over Hyderabad (red line) (b) located $2^{\circ}$ south-west of Hyderabad (blue line) during the month of March 2010.

Thus, to assess this inventory over Hyderabad (our study region), we estimated $\mathrm{BC}$ emissions from aircraft over this region using previously reported values for the fuel efficiency of different airline carriers (Kwan and Rutherford, 2015), seating capacity of the carriers (websites of different airlines), density of aviation fuel used (Cookson and Smith, 1990; Arkoudeas et al., 2003; Outcalt et al., 2009; Blakey et al., 2011) in the Indian region, BC emission index for the aviation fuel (Stettler et al., 2013) and actual data on air traffic over Hyderabad obtained from air traffic control (Babu et al., 2011). Depending on such an evaluation of the MACCity emissions database over the Hyderabad region, we have modified the inventory emissions by a corresponding scaling factor. Additionally, by acknowledging the coarse resolution of the MACCity inventory, the "line-source" nature of the freshly emitted aircraft trail and the finer resolution of our model simulations, we confine the aircraft $\mathrm{BC}$ emissions to a width of $2 \mathrm{~km}$ and a height of $100 \mathrm{~m}$. The mass conservation of the emitted BC due to such confinement leads to an additional scaling factor. The total scaling factor becomes the product of these two scaling factors. The modified emissions are formulated by multiplying the original emissions by the aforementioned scaling factors.

\subsection{Computation of atmospheric heating rate}

The atmospheric heating rates due to the vertical profiles of BC (measured and simulated) are computed using a discrete ordinate radiative transfer model (Santa Barbara DISORT Atmospheric Radiative Transfer; SBDART; Ricchiazzi et al., 1998). SBDART solves radiative transfer equations considering a plane-parallel atmosphere. Aerosols are specified in the model through total aerosol optical depth, single scattering albedo (SSA) and the Legendre moments of the scattering phase function for the assumed aerosol mixture at every vertical layer. To compute the heating rate associated with the observed BC profiles, the required layer-wise total AODs were computed using vertical profile total extinction coefficients from CALIOP (Cloud-Aerosol Lidar with Orthogonal Polarization) on-board the CALIPSO (Cloud-Aerosol Lidar Pathfinder Satellite Observation) satellite. The level 2 extinction coefficient data from CALIPSO were cloud-screened using the standard recommended cloud-screening algorithm (https://www-calipso.larc.nasa.gov/resources/calipso_ users_guide/tools/index.php). This makes use of flags like AVD (atmospheric volume description), CAD score (cloud aerosol detection flag), extinction coefficient uncertainty and extinction coefficient quality control to separate aerosol from clouds. The final vertical profile of the extinction coefficient was the mean of all such cloud-screened vertical profiles which fall within $\pm 1.5^{\circ}$ of the balloon flight location in the $x-y$ direction and \pm 20 days of the balloon flight date. Such an averaging was done for a mean picture of the aerosol loading over the balloon flight region. To obtain the required SSA we made use of the observed vertical profile of BC and the OPAC (Optical Properties of Aerosol and Clouds) model (Hess et al., 1998). OPAC provides optical properties like the extinction coefficient, absorption coefficient, scattering coefficient, single scattering albedo, asymmetry parameter and phase function for the prescribed mixture of aerosol species. In OPAC, we prescribed the measured vertical distribution of $\mathrm{BC}$ to get the corresponding absorption coefficients. These absorption coefficients, along with extinction coefficients from CALIPSO, were used to obtain the SSA. Finally, in order to compute the Legendre moments of the scattering phase function, we execute OPAC with one of its preset aerosol mixtures, "urban", as it is best suited for our observational location. This aerosol mixture has water soluble species (28000 particles $\left.\mathrm{cm}^{-3}\right)$, insoluble species (1.5 particles $\mathrm{cm}^{-3}$ ) and soot (130000 particles $\mathrm{cm}^{-3}$ ). For the urban aerosol mixture, we derived the scattering phase function and computed eight Legendre moments of the scattering phase function. Along with the aforementioned primary inputs, SBDART requires some additional inputs, such as the mean state of the atmospheric vari- 
ables temperature and pressure on every vertical level and the vertical profile of specific humidity and ozone. These inputs were taken from the SBDART database under the tropical category, which suits our observation location (Hyderabad). Additionally, spectrally varying surface albedo values for Hyderabad were taken from the MODIS surface reflectance product (MOD09CMG). This daily level 3 product provides surface reflectance for seven bands $(469,555,645$, $858.8,1240,1640$ and $2130 \mathrm{~nm}$ ) at $0.05^{\circ}$ of resolution. With all these inputs, the SBDART model was executed with eight streams in the radiative transfer calculations with $7.5^{\circ}$ of resolution for solar zenith angles varying from 0 to 180 . The net radiative fluxes were computed at the top and bottom of every vertical layer starting from the surface to $100 \mathrm{~km}$. A similar run of SBDART was conducted without the prescription of aerosols. Using radiative fluxes from these two runs, radiative forcing within each layer was estimated using

$\Delta F=$ Flux $_{\mathrm{NA}}-$ Flux $_{\mathrm{A}}$,

where Flux $x_{N A}$ is radiative flux in the absence of aerosols $\left(\mathrm{W} \mathrm{m}^{-2}\right)$ and Flux $_{\mathrm{A}}$ is radiative flux in the presence of aerosols $\left(\mathrm{W} \mathrm{m}^{-2}\right)$.

The change in radiative fluxes in each layer due to aerosol is the amount of energy absorbed in the layer due to aerosols. Corresponding atmospheric heating rates were computed using Liou (2002):

$\mathrm{d} T / \mathrm{d} t=\left(g / C_{\mathrm{p}}\right)(\Delta F / \Delta p)$,

where $\mathrm{d} T / \mathrm{d} t$ is the heating rate $\left(\mathrm{K} \mathrm{s}^{-1}\right), g$ is the acceleration due to gravity, $C_{\mathrm{p}}$ is the specific heat capacity of air at constant pressure $\left(C_{\mathrm{p}}=1006 \mathrm{~J} \mathrm{~kg}^{-1} \mathrm{k}^{-1}\right)$ and $p$ is the atmospheric pressure (Satheesh and Ramanathan, 2000). The heating rates $\left(\mathrm{K} \mathrm{day}^{-1}\right)$ were then averaged for $24 \mathrm{~h}$.

The vertical extents of the heating rate profiles from the measurements were limited due to the availability of extinction coefficient data from CALIPSO over the region of interest. Such a limitation does not exist for model data, and hence we have computed the atmospheric heating rates using the model results. To compute the atmospheric heating rates using model data, we follow exactly the same aforementioned procedure. The only differences are that we use extinction coefficient data from model simulations instead of the CALIPSO satellite and SSA from model simulations instead of deriving it from the observed BC.

\section{Results}

\subsection{Observed vertical profiles of $\mathrm{BC}$}

The vertical profiles of $\mathrm{BC}$ derived from flight measurements are shown in Fig. 2a-c, in which each profile is the average of the ascent and descent profiles for that flight. All the profiles revealed sharp and confined peaks in BC concentration in the free troposphere above a near-steady mass concentration within the planetary boundary layer $(\sim 2 \mathrm{~km}$ for
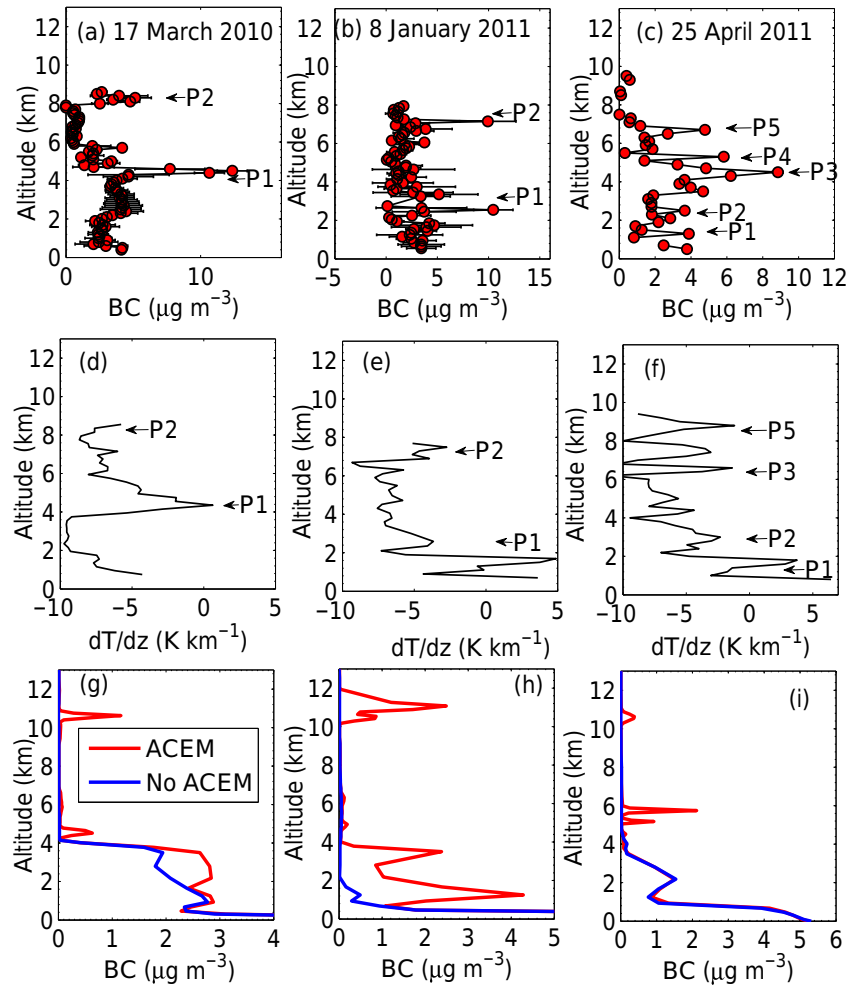

Figure 2. Observed vertical profile of BC over Hyderabad obtained from balloon measurements on (a) 17 March 2010, (b) 8 January 2011 and (c) 25 April 2011. The high-altitude BC peaks in each profile are identified by P1 to P5. Observed vertical profile of $\mathrm{d} T / \mathrm{d} z\left(\mathrm{~K} \mathrm{~km}^{-1}\right)$ over the Hyderabad region obtained from balloon measurements on (d) 17 March 2010, (e) 8 January 2011 and (f) 25 April 2011. The locations corresponding to high-altitude BC peaks are identified by P1 to P5. Model-simulated vertical profile of $\mathrm{BC}$ over the area in the vicinity of the balloon flight region for "No ACEM" (blue line; control run) and ACEM (red line; runs with prescription of aircraft BC emissions) on (g) 17 March 2010, (h) 8 January 2011 and (i) 25 April 2011.

pre-monsoon and $\sim 1 \mathrm{~km}$ for winter). These peaks are identified on the respective profiles in Fig. 2a-c. It is also seen very clearly that the sharp and most prominent peak occurred between 4 and $5 \mathrm{~km}$ in the first and last profiles (Fig. 2a and c), which incidentally correspond to the pre-monsoon flights; it occurred at a slightly lower altitude (between 2 and $3 \mathrm{~km}$ ) in the winter profile. The highest altitude layer seen in the profiles was in the vicinity of 7-9 km, though the amplitude of it is much smaller than the layer seen at around $4.5 \mathrm{~km}$. With the help of temperature data from the collocated meteorological payloads, we evaluated the environmental lapse rate profile for each of these profiles and the mean profile for each flight is shown in Fig. $2 \mathrm{~d}-\mathrm{f}$ following the same order as in Fig. 2a-c. It is clearly seen that in the vicinity of the prominent $\mathrm{BC}$ peaks ( $\mathrm{P} 1$ to $\mathrm{P} 5$ in Fig. $2 \mathrm{a}-\mathrm{c}$ ) there is a large reduction in the environmental lapse rate (sometimes close to zero), e.g. at $4.5 \mathrm{~km}$ during March 2010 (Fig. 2d), around 

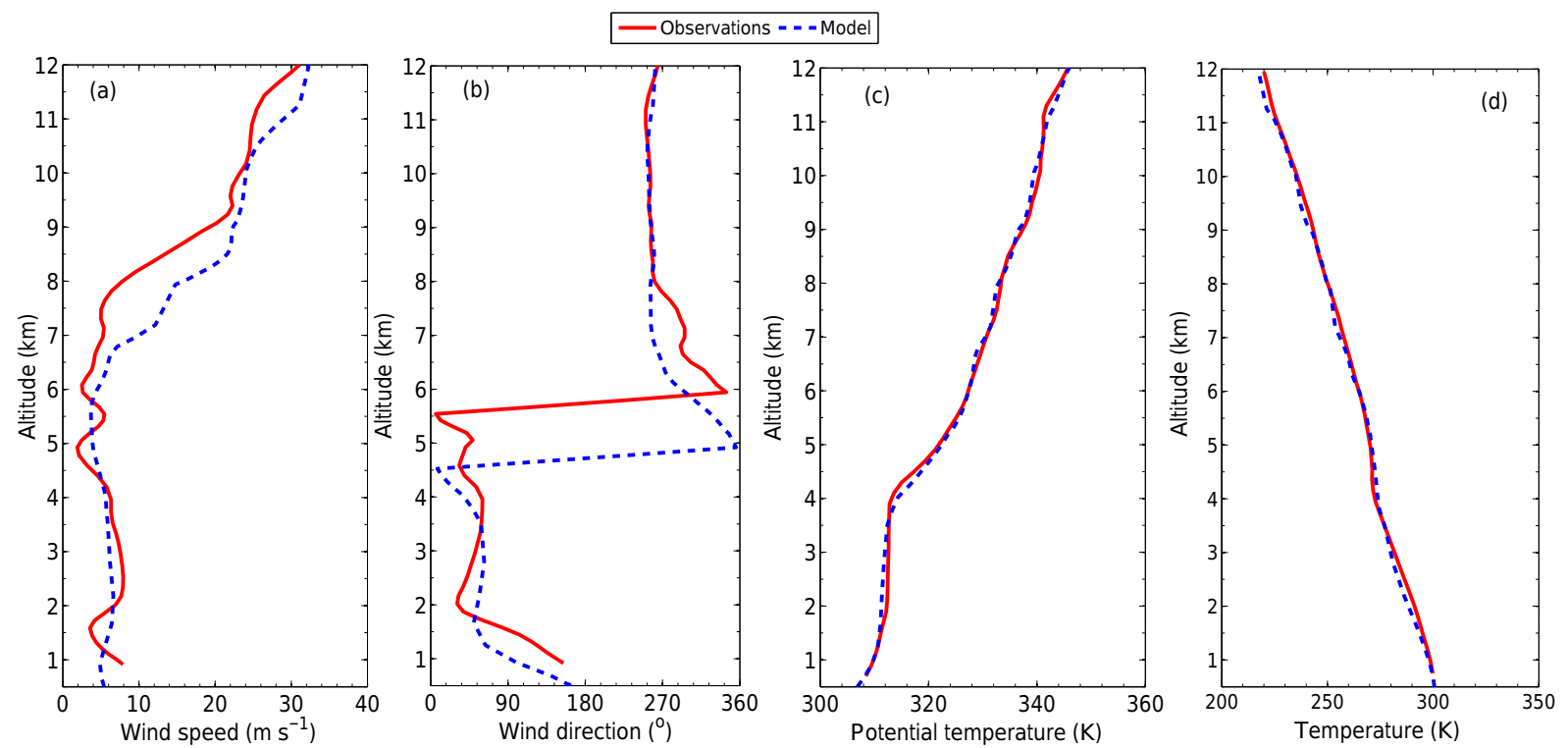

Figure 3. Comparison between the model-simulated meteorological variables in the "No ACEM" (control) run and the corresponding observations over the balloon flight region on 17 March 2010 for (a) wind speed, (b) wind direction, (c) potential temperature and (d) temperature.

2-3 and $7 \mathrm{~km}$ during January 2011 (Fig. 2e) and around 4-5 and 6-7 km during April 2011 (Fig. 2f). The lapse rate profile during April 2011 (Fig. 2f) shows multiple spikes, possibly due to a higher number of peaks in the corresponding $\mathrm{BC}$ profile (Fig. 2c). Since the raw temperature data are very noisy, we have smoothened the data using two fixed points and two moving points (average filter). Such reductions in temperature lapse rate would affect the local stability scenario. While the occurrence of high $\mathrm{BC}$ below $3 \mathrm{~km}$ can be explained by the boundary layer dynamics, high $\mathrm{BC}$ values at higher levels, especially at $7-9 \mathrm{~km}$, remained a mystery. Babu et al. (2011) hypothesised that the occurrence of such $\mathrm{BC}$ peaks at high altitudes could be associated with local sources of BC at those altitudes, as 4-5 and 8-9 km are the preferred corridors for aircraft flying over Hyderabad. With a motivation to test this hypothesis and also to estimate the climatic implications of such BC layers, we investigate the causes for the occurrence of such sharp and confined BC peaks at higher altitudes using a regional online chemistry transport model. Crucial findings from this study are reported and possible ramifications are discussed.

\subsection{Meteorological evaluation of the model}

Meteorological processes like advection, diffusion and deposition play significant roles in controlling the concentration of pollutants near the surface and their vertical distribution in the troposphere (Govardhan et al., 2015). Hence, before inspecting the model-simulated vertical profile of $\mathrm{BC}$, we first examine the performance of the model in simulating meteorology over the region of interest. We show such comparisons for the March 2010 NoACEM simulations as representative. The model-simulated meteorological parameters are averaged over the balloon flight region and are then compared with the corresponding observations from the balloon flight. Three-point running mean smoothing is used to smooth the observational and simulated vertical profiles. Firstly, we have compared the model-simulated vertical profile of horizontal wind speed (blue line, Fig. 3a) and direction (blue line, Fig. 3b) with the corresponding observations (red line, Fig. 3a and red line, Fig. 3b) available from the balloon flight measurements (deduced from the GPS data onboard the balloon). The figures depict relatively weak (less than $10 \mathrm{~m} \mathrm{~s}^{-1}$ ), low-level, northerly-north-easterly winds up to around $5 \mathrm{~km}$. Beyond this altitude, the winds change direction gradually and become westerlies above $8 \mathrm{~km}$. The wind speeds also increase drastically beyond $8 \mathrm{~km}$ and reach a value of $20-25 \mathrm{~m} \mathrm{~s}^{-1}$ at a height of $9 \mathrm{~km}$ and beyond. While the model-simulated vertical variation in wind speed (blue line, Fig. 3a) and direction (blue line, Fig. 3b) agree broadly with the measurements, they differ in details and magnitudes. In model simulations, the change in wind direction starts occurring at an altitude $\sim 1 \mathrm{~km}$ lower than in the observations. The large increase in wind speed beyond $8 \mathrm{~km}$ of altitude is satisfactorily captured by the model. Thus, with some disagreement in the actual magnitudes, the model captures the broad features of horizontal advection strength (wind speed) and nature (wind direction) over the balloon flight domain vis-à-vis the measurements. We next examine the model simulations of vertical stability over the flight domain by comparing the model-simulated vertical profiles of potential temperature $(\theta)$ with the corresponding profiles from the balloon data. The observed profile (red line, Fig. 3c) shows a stable layer ( $\theta$ increases with height) up to the first $2 \mathrm{~km}$ of the 
lower troposphere. Above this layer, there is a thick, wellmixed layer up to a height of $4 \mathrm{~km}$ in which $\theta$ remains almost height invariant. Above this height, the atmosphere remains largely stable with an increase in $\theta$ with height. The modelled altitude variation in $\theta$ (blue line, Fig. 3c) generally matches the measurements, barring a few discrepancies such as the extent of the stable and well-mixed layer in the lower atmosphere and the magnitude of $\theta$ in the vicinity of the primary BC maxima in observations (around $4-4.5 \mathrm{~km}$; Fig. 2a). The model captures the stable layer lying up to around $1.5 \mathrm{~km}$, which is similar to that seen in observations (up to $2 \mathrm{~km}$; red line, Fig. 3c). A convectively unstable, wellmixed layer ( $\theta$ constant) extending up to a height of $3.5 \mathrm{~km}$ occurs above this layer, which is akin to observations (up to $4 \mathrm{~km}$; red line, Fig. 3c), with an underestimation in $\theta$ values. Beyond this height, the model does not show any sign of instability, while $\theta$ increases with height in agreement with the observations but with differences in the magnitudes. Thus, the model-simulated vertical profile of $\theta$ also appears to be broadly comparable to the observed profile with some differences. Examining the vertical thermal structure, we have also compared the model simulations of the vertical profile of temperature with the corresponding measurements from the flight. While generally showing a reduction in temperature with height similar to the observations (red line, Fig. 3d), the model (blue line, Fig. 3d) shows discrepancies in actual magnitudes vis-à-vis the observations $(-1.7$ to $+3.4 \mathrm{~K})$, as in the case of the other meteorological variables. Possibly owing to the existence of the primary BC peak between 4 and $5 \mathrm{~km}$, the observations (red line, Fig. 3d) depict a near-steady temperature within the particular altitude layer. The model (blue line, Fig. 3d), on the other hand, fails to capture this feature. Thus, along with some differences in the details, the model simulations capture some of the large-scale features of the meteorology over the balloon flight region vis-à-vis the observations.

\subsection{Simulated vertical profile of $\mathrm{BC}$}

With the above broad agreement in the meteorological fields, we proceeded to examine and evaluate the model-simulated vertical profile of $\mathrm{BC}$ in the vicinity of the balloon flight domain (blue line, Fig. 2g-i) in the NoACEM configuration. For 17 March 2010, the model simulations (NoACEM) show considerable differences vis-à-vis the observed vertical profile of BC (Fig. 2a). The magnitudes of the simulated BC (blue line, Fig. 2g) show a relatively good comparison with the observations only over the lowermost altitudes, i.e. below $3.5 \mathrm{~km}$. Above that altitude, the two profiles completely differ from each other; while the observations (Fig. 2a) show an increase in $\mathrm{BC}$ followed by a sharp peak at $4.5 \mathrm{~km}\left(\mathrm{BC}>12 \mu \mathrm{g} \mathrm{m}^{-3}\right)$, the model (Fig. $2 \mathrm{~g}$ ) displays a rapid decrease in $\mathrm{BC}$ concentration with altitude, with no sign of the elevated (high-altitude) layers of high $\mathrm{BC}$ concentration seen in the measurements. Thus, though the model satisfactorily simulates the meteorology over the flight domain, it does not simulate the observed vertical profile of BC. The results for the other two flights are shown in Fig. 2h and i. During January 2011, the model simulations (NoACEM; blue line, Fig. 2h) show a rapid reduction in $\mathrm{BC}$ within the first $1 \mathrm{~km}$. There is no sign of sharp and confined peaks beyond this height, unlike the corresponding observations (Fig. 2b). During April 2011, the model simulations (NoACEM; blue line, Fig. 2i) show a sharp reduction in $\mathrm{BC}$ within the first $1 \mathrm{~km}$. Beyond this height, a sharp peak in $\mathrm{BC}$ is seen with a maximum near $2 \mathrm{~km}$. A relatively gradual reduction in $\mathrm{BC}$ occurs beyond this height up to $4 \mathrm{~km}$, followed by a flat steady BC profile with very low values above that height (blue line, Fig. 2i). Thus, none of the model simulations capture the sharp confined BC peaks (or the elevated $\mathrm{BC}$ layers) occurring at higher altitudes. This strongly suggests that the meteorological factors alone cannot be responsible for the existence of the elevated BC layers. To shed more light on this, we considered other hypotheses.

The meteorology (observed and simulated) being benign for all the cases and the possibility of any long-range transport of $\mathrm{BC}$ from other locations being an unlikely cause for such high concentrations (Babu et al., 2011), one has to look for a local injection of $\mathrm{BC}$ aerosols in the middle and upper troposphere because surface-based emissions would not lead to elevated BC layers at altitudes of 4-5 or 7-9 km. In this context, emissions from commercial air traffic (that overfly Hyderabad and land and take off from there) assume significance. In their first reporting of the elevated layers, Babu et al. (2011) hypothesised the role of such emissions and obtained an approximate estimate of air traffic over the study location; about 200 aircraft overfly Hyderabad in the corridor at $8-10 \mathrm{~km}$ and another $250-300$ use the corridor at $4-5 \mathrm{~km}$ in the course of landing and taking off from the airport. We next evaluate elevated emissions due to aircraft as a likely candidate for these high concentrations.

\subsection{Simulated vertical profile of $\mathrm{BC}$ with aircraft $\mathrm{BC}$ emissions}

We examine the outcome of the prescription of $\mathrm{BC}$ emissions from aircraft on the modelled vertical profile of $\mathrm{BC}$ in Fig. $2 g-i$ in the vicinity of the balloon flight domain for the 3 balloon flight days. It is quite interesting to note that, upon the prescription of $\mathrm{BC}$ emissions from aircraft, the model simulations (ACEM) show sharp layers in the vertical profiles akin to the observed BC profiles (red line, Fig. 2g-i), which are not simulated otherwise (NoACEM control run). Though the actual altitudes and the magnitudes of the BC layers differ in comparison with the observations, the sharpness of the modelled $\mathrm{BC}$ layers makes them look similar to the observed $\mathrm{BC}$ layers. The two peaks in the $\mathrm{BC}$ profile during March (red line, Fig. 2g), the lower and upper level BC peaks during January (red line, Fig. 2h) and the clustered BC peaks during April (red line, Fig. 2i) are well simulated by 

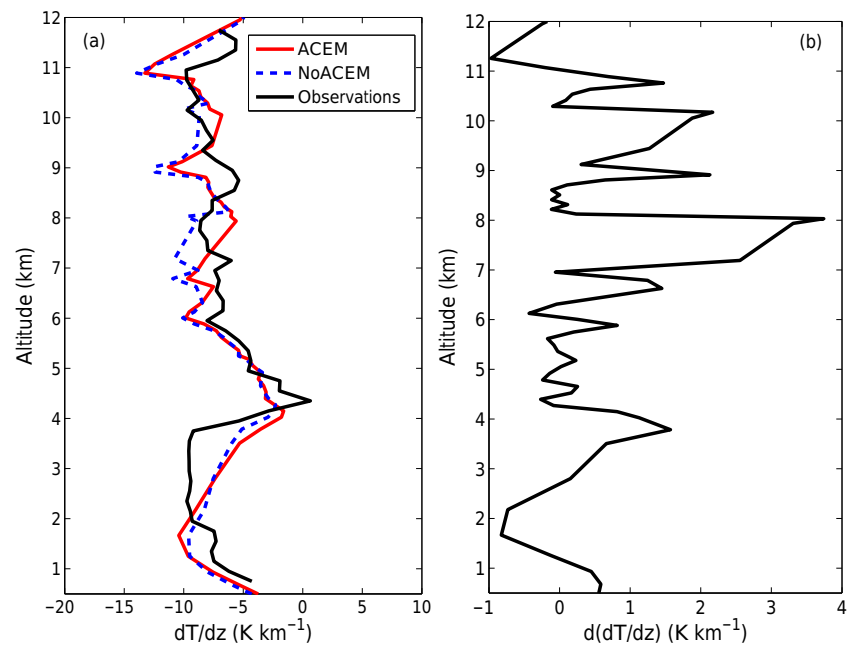

Figure 4. (a) Vertical profile of $\mathrm{d} T / \mathrm{d} z\left(\mathrm{~K} \mathrm{~km}^{-1}\right)$ over the balloon flight region on 17 March 2010 from (black line) observations, (blue dashed line) simulations without $\mathrm{BC}$ emissions from aircraft (NoACEM) and (red line) simulations with BC emissions from aircraft (ACEM). (b) Vertical profile of difference in $\mathrm{d} T / \mathrm{d} z$ values for two model simulations; $\mathrm{d}(\mathrm{d} T / \mathrm{d} z)=(\mathrm{d} T / \mathrm{d} z)_{A C E M}-$ $(\mathrm{d} T / \mathrm{d} z)_{\text {NoACEM }}$

the model only after the prescription of $\mathrm{BC}$ emissions from aircraft. Thus, even for the model with realistic meteorology, the high-altitude $\mathrm{BC}$ peaks and layers are captured only when the high-altitude sources of $\mathrm{BC}$ are prescribed. This clearly highlights the role played by aircraft emissions of $\mathrm{BC}$ in the creation of the high-altitude $\mathrm{BC}$ peaks, which remained as a hypothesis earlier. Additionally, as a consequence of such high-altitude $\mathrm{BC}$ emissions, the modelled vertical profile of temperature lapse rate over the balloon flight region shows a reduction in magnitude in the ACEM case compared to the NoACEM case, indicating warming due to BC (Fig. 4a). The corresponding differences in the temperature lapse rate $\left(\mathrm{d}(\mathrm{d} T / \mathrm{d} z)=(\mathrm{d} T / \mathrm{d} z)_{\text {ACEM }}-(\mathrm{d} T / \mathrm{d} z)_{\text {NoACEM }}\right)$ appear to be higher, especially at higher altitudes of $4 \mathrm{~km}$ and beyond $7 \mathrm{~km}$ (Fig. 4b). Such a reduction in the magnitude of the temperature lapse rate values results in a better match between the model simulations and the corresponding observations of temperature lapse rate, especially at higher altitudes (from 6 to $8 \mathrm{~km}$ and from 9 to $9.5 \mathrm{~km}$; Fig. $4 \mathrm{a}$ ).

We carried out one more model simulation, in which we prescribed the emissions of $\mathrm{BC}$ from biomass burning activities using the Fire INventory from NCAR (FINN) version 1.5 (Wiedinmyer et al., 2011) biomass burning data. The FINN provides high-resolution global emission estimates from such open burning activities. The temporal resolution of the inventory is 1 day, while the spatial resolution is $1 \mathrm{~km}^{2}$. In our simulations, we allowed such emissions from biomass burning to lift vertically following the online plume-rise module (Freitas et al., 2007). However, the model could not simulate the observed sharp and confined BC peaks (figure not shown) when we switched off the prescription of $\mathrm{BC}$ emissions from aircraft. This clearly shows the important role of aircraft BC emissions in causing high-altitude BC peaks.

\subsection{Sensitivity of the vertical profile of $\mathrm{BC}$ to the surface level emissions}

To test the robustness of the simulated high-altitude BC peaks, we have also examined the impact of near-surface emissions of $\mathrm{BC}$ on the elevated layers. For this, we have done a similar simulation with aircraft $\mathrm{BC}$ emissions, in which we turned off the near-surface fossil fuel emissions of $\mathrm{BC}$ over the model domain. We then examined the effect of this on the simulated vertical profile of BC in Fig. 5. It can be clearly seen from this figure that the vertical profiles simulated by the two runs (SE, the run with prescribed nearsurface anthropogenic emissions of $\mathrm{BC}$, and $\mathrm{N}-\mathrm{SE}$, the run with near-surface anthropogenic BC emissions turned off) differ only in the lower altitude region up to a height of about $4 \mathrm{~km}$ (probably the altitude up to which BC could be lofted by the convection). Beyond $4 \mathrm{~km}$, the profiles are largely similar, implying that the elevated $\mathrm{BC}$ layers are insensitive to surface $\mathrm{BC}$ emissions. The correlation coefficient between the two $\mathrm{BC}$ profiles beyond $4 \mathrm{~km}$ comes out to be 0.97 , which is $99.99 \%$ significant. Moreover, the magnitudes of BC in the two profiles show good agreement with a difference limited to only $0.1 \mu \mathrm{g} \mathrm{m}^{-3}$. Thus, our model simulations indicate that the high-altitude peaks in $\mathrm{BC}$ are not a result of the convective lifting of near-surface $\mathrm{BC}$, but they are indeed caused by $\mathrm{BC}$ emissions (injection of $\mathrm{BC}$ ) at higher altitudes by aircraft.

\subsection{Model-simulated elevated sharp BC layers: seasonal scenario}

We noticed that the model, WRF-Chem, produces the elevated sharp peaks of $\mathrm{BC}$ akin to the observations upon the prescription of aircraft $\mathrm{BC}$ emissions from the regionally fine-tuned MACCity inventory. We now proceed to examine the seasonal behaviour of such elevated sharp BC layers within the model simulations. For this, we carried out 1-month model simulations during each season of the year 2010, i.e. January, March, July and October, which are representative of winter and the pre-monsoon, monsoon and post-monsoon seasons. Keeping in mind the limited width and the dynamic behaviour of the horizontal location of the aircraft-emitted trail, we have computed the seasonal probability of the occurrence of a high-altitude $\mathrm{BC}$ peak at every point within the domain instead of plotting a monthly mean vertical profile of $\mathrm{BC}$ averaged over a region.

\subsubsection{Probability of occurrence of sharp BC peak within 9-11 km}

For every point within the domain, the probability of the occurrence of a sharp BC peak within $9-11 \mathrm{~km}$ is computed by 


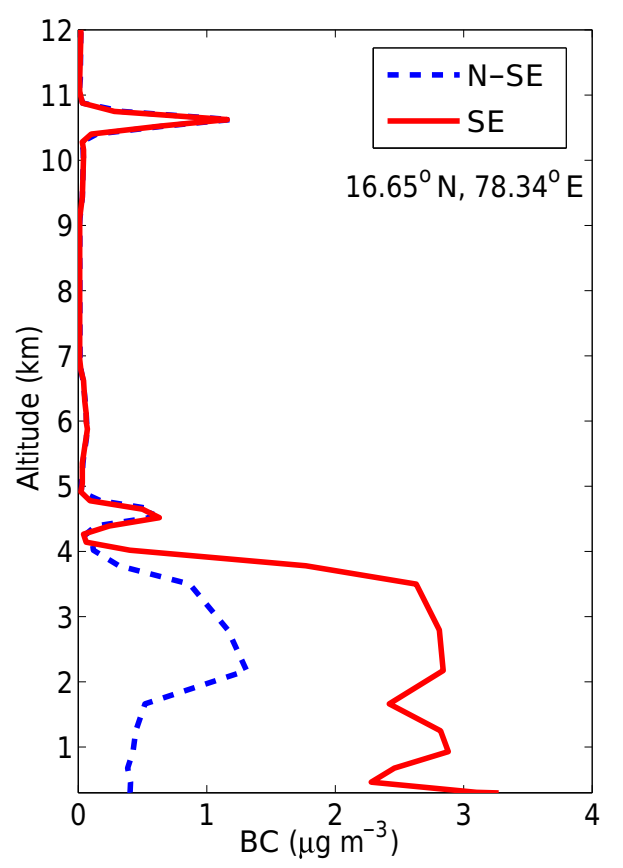

Figure 5. Model-simulated vertical profile of BC on 17 March 2010 for N-SE runs (model simulations without prescription of surface level anthropogenic $\mathrm{BC}$ emissions) and SE configurations (model simulations with prescription of surface level anthropogenic BC emissions).

examining the maximum value of the simulated $\mathrm{BC}$ within the $9-11 \mathrm{~km}$ altitude band and that within the $7-9 \mathrm{~km}$ altitude band. When the ratio of maximum BC magnitude within the 9-11 km band to that within the $7-9 \mathrm{~km}$ band is more than 3 , we considered it the occurrence of a high-altitude sharp $\mathrm{BC}$ peak within the $9-11 \mathrm{~km}$ altitude band. The probability of the occurrence of a sharp BC peak within the 9-11 km band for the entire month is computed as follows:

$p_{(9-11)}=\frac{T_{(\text {Peak:9-11) }}}{T_{\text {Total }}}$,

where $p_{(9-11)}$ is the probability of the occurrence of a sharp BC peak within the $9-11 \mathrm{~km}$ altitude band, $T_{\text {(Peak:9-11) }}$ is the number of instances when a sharp BC peak occurs at the 9-11 km altitude band and $T_{\text {Total }}=240$ for the entire month with a 3-hourly output frequency.

Such a computation of $p_{(9-11)}$ is done for all the months of the model simulations and shown in Fig. 6. During January 2010 (Fig. 6a) and March 2010 (Fig. 6b), the probability of an upper level $(9-11 \mathrm{~km})$ sharp peak in BC within the model domain is as high as $60 \%$ over the area in the south-west part of the domain. This looks to be primarily related to the location of the aircraft-emitted trail in the emissions inventory. Around a $40 \%$ chance of a sharp peak at the upper level $(9-11 \mathrm{~km})$ is seen at various locations which roughly occur over the location of the aircraft emissions in the inventory and are further controlled by the direction of
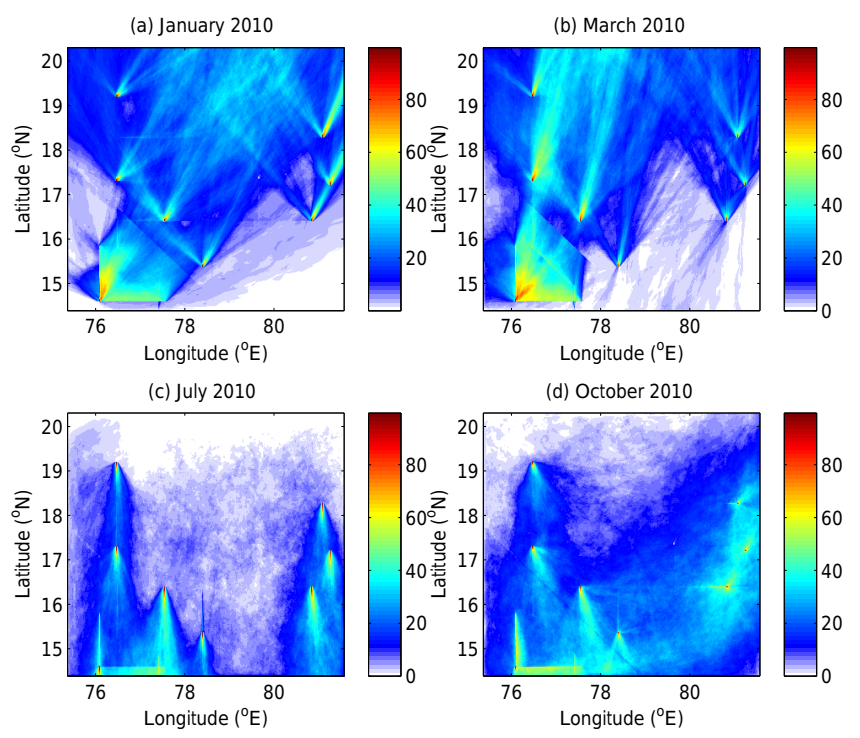

Figure 6. Spatial plot of probability (\%) of occurrence of a BC peak within the altitude band of 9-11 km for the model simulations carried out during (a) January 2010, (b) March 2010, (c) July 2010 and (d) October 2010

the prevailing upper level winds. For the monsoonal period, i.e. during the month of July 2010 (Fig. 6c), such probability values are reduced with most of the region showing less than $10 \%$ probability. Such a reduction in $p_{(9-11)}$ over the domain looks to be the result of the convective lifting of $\mathrm{BC}$ during the monsoon (which is relatively less during the premonsoon and post-monsoon). This results in a more uniform concentration of $\mathrm{BC}$ at the elevated altitudes, causing the removal of such sharp peaks in BC but an increased abundance of $\mathrm{BC}$ at those altitudes as shown in Fig. 7. During the month of October 2010 (Fig. 6d), the $p_{(9-11)}$ once again reaches as high as $50 \%$, with the specific aircraft emission zones showing higher values. The spatial pattern of the probability appears to be roughly in contrast to that during January or March 2010. This behaviour could be due to the difference between the direction of the prevailing winds during January and March and that during October. Thus, in summary, the probability of a BC peak at $9-11 \mathrm{~km}$ of altitude in the model simulations looks to be dependent on the season and the location.

\subsubsection{Probability of occurrence of sharp BC peak within 4-5 km}

Following a similar exercise, we have estimated the probability of the occurrence of a BC peak within the $4-5 \mathrm{~km}$ altitude band. The lower level (4-5 km) peak in BC is identified when the maxima of the $\mathrm{BC}$ magnitude within the $4-5 \mathrm{~km}$ altitude band are more than twice those of the neighbouring altitude bands. The spatial plot of such probability values for each month is shown in Fig. 8. In general, it can be seen that the 


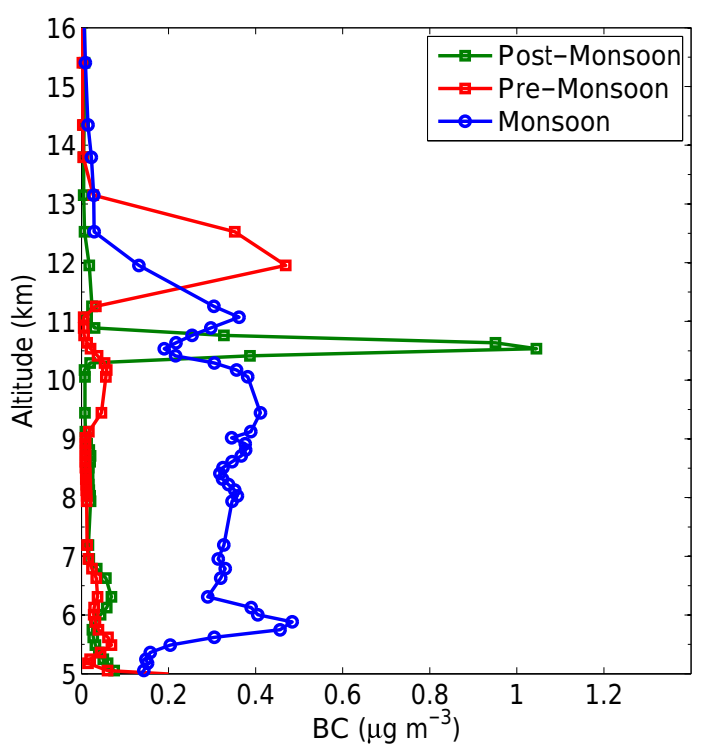

Figure 7. The model-simulated vertical profile of BC mass concentrations $\left(\mu \mathrm{g} \mathrm{m}^{-3}\right)$ in the vicinity of the balloon flight domain during different seasons in 2010: pre-monsoon (red line), monsoon (blue line) and post-monsoon (green line).

probability of a lower level (here $4-5 \mathrm{~km}$ ) peak in the simulated BC (Fig. 8) is lower than for the upper level (9-11 km; Fig. 6) peak within the model simulations. This could possibly be linked to the differences associated with the altitude variation and the magnitudes of $\mathrm{BC}$ emissions from aircraft over the 9-11 km altitude band vis-à-vis the $4-5 \mathrm{~km}$ altitude band within the inventory. During July 2010, the monsoonal convection reduces the $p_{4-5}$ values by vertically lifting $\mathrm{BC}$ throughout the column, getting rid of the sharp BC peaks as shown in Fig. 7.

\subsection{Atmospheric heating rate due to the observed and modelled BC vertical profile}

As a strong absorber of radiation over a wide spectral band, the elevated BC layers would absorb incoming solar radiation, which would then heat up the atmosphere locally and alter the vertical stability. In this section, we compute the atmospheric heating caused by the observed and modelled BC vertical profiles. The methodology that we follow to compute the atmospheric heating rates due to $\mathrm{BC}$ is similar to that followed by Babu et al. (2002) and Babu et al. (2011).

\subsubsection{Atmospheric heating rates due to observed BC}

Following the procedure outlined in Sect. 2.4, we have computed the atmospheric heating rates due to the measured $\mathrm{BC}$ profiles for the three balloon flights. The heating rate profiles are presented in Fig. 9a, b and c for the March, January and April flights respectively. The vertical extent of the profiles is limited to the availability of the extinction coefficient data

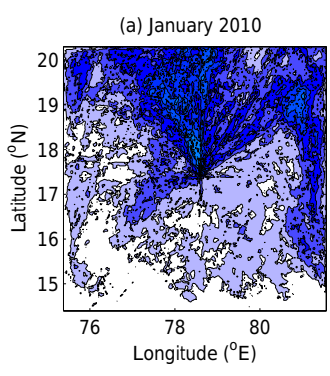

(c) July 2010

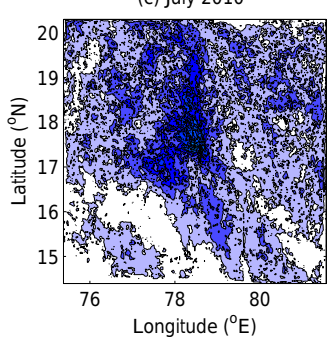

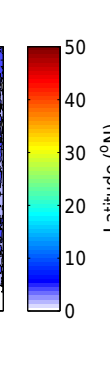

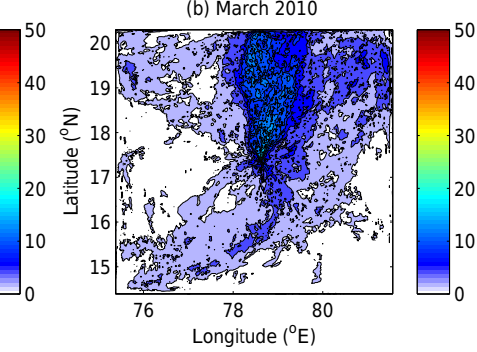

(d) October 2010

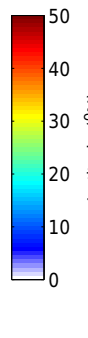

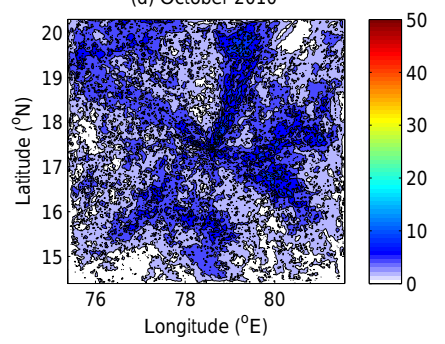

Figure 8. Spatial plot of probability (\%) of occurrence of a BC peak within the altitude band of 4-5 km for the model simulations carried out during (a) January 2010, (b) March 2010, (c) July 2010 and (d) October 2010.
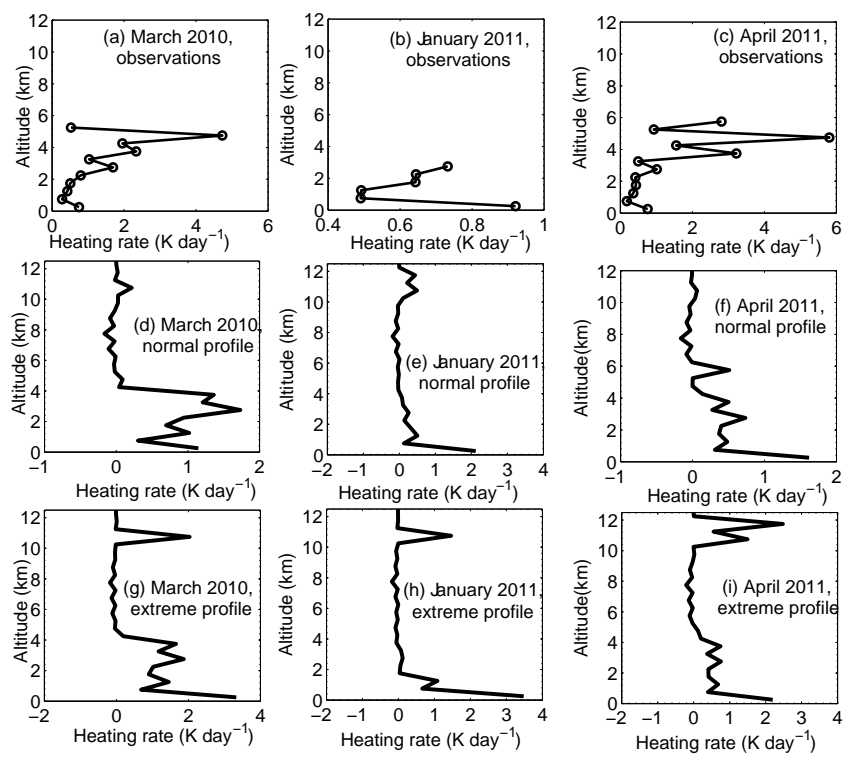

Figure 9. Vertical profiles of atmospheric heating rates corresponding to the observed BC profiles during (a) March 2010, (b) January 2011 and (c) April 2011. Similar vertical profiles of atmospheric heating rates corresponding to the model-simulated BC profiles during (d, g) March 2010, (e, h) January 2011 and (f, i) April 2011.

from the CALIPSO satellite. During March 2010 (Fig. 9a), the heating rates are seen to be within 0.5 to $1 \mathrm{~K} \mathrm{day}^{-1}$ up to $2-2.5 \mathrm{~km}$ in the atmosphere. The denser atmosphere could also be one of the factors responsible for such low values of heating rates at lower altitudes. Beyond this height, a large 


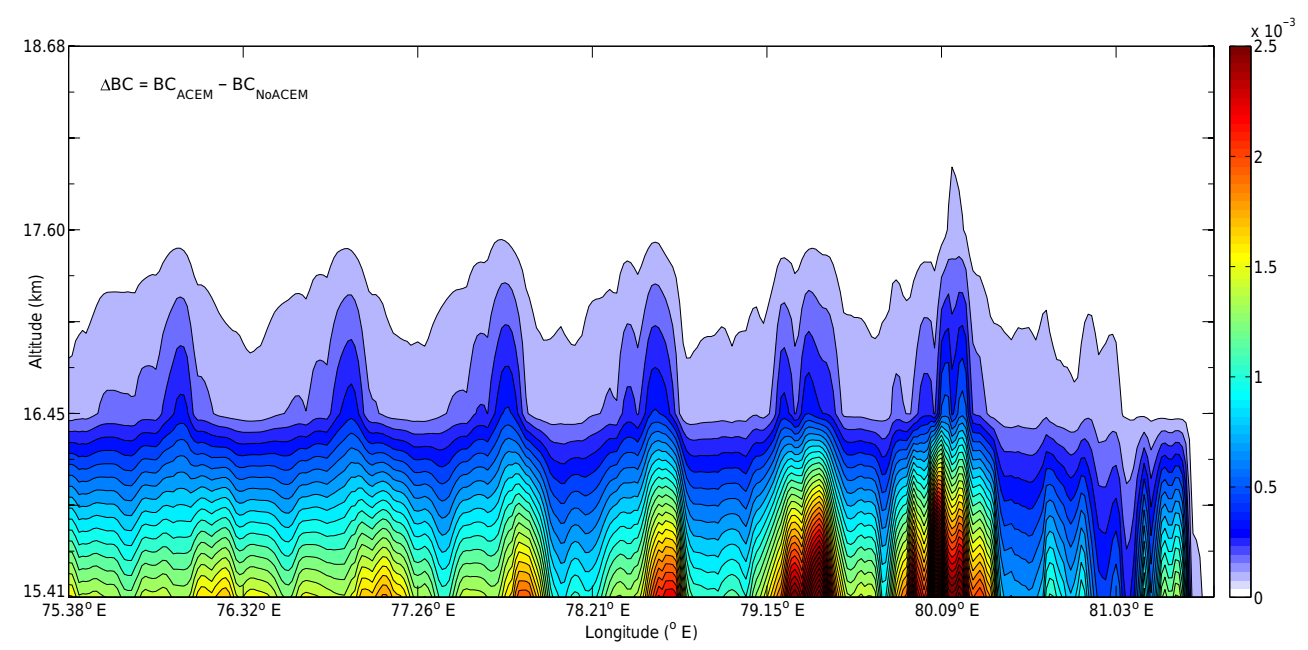

Figure 10. Vertical profile of the difference in BC mass concentration $\left(\mu \mathrm{g} \mathrm{m}^{-3}\right)$ in ACEM runs vis-à-vis NoACEM runs averaged for the entire duration (1 week covering strong convective activity over the model domain) of the model simulations carried out during July 2010. Here, $\triangle \mathrm{BC}=\mathrm{BC}_{\mathrm{ACEM}}-\mathrm{BC}_{\mathrm{NoACEM}}$.

increase in heating rates could be seen up to $\sim 5 \mathrm{~km}$. The heating rate maxima $\left(\sim 5 \mathrm{~K} \mathrm{day}^{-1}\right)$ are seen to occur around the height of the BC maxima (Fig. 2a). Such a large heating rate could cause the observed reduction in temperature lapse rate around those altitudes (Fig. 2d). During the winter flight (January 2011; Fig. 9b), the observed BC profiles along with the extinction coefficient profiles from CALIPSO cause more heating near the surface. The corresponding heating rates at near-surface levels are even higher than during the summer months (March 2010, Fig. 9a; April 2011, Fig. 9c). The heating rate profile during April 2011 (Fig. 9c) shows similar features as in March 2010 (Fig. 9a). The maxima in the heating rates also occur around the elevated $\mathrm{BC}$ layers with comparable magnitudes. As expected, since the observed BC profile during April 2011 (Fig. 2c) shows more local peaks compared to March 2010 (Fig. 2a), the heating rate profile during April 2011 also shows more pronounced spikes vis-à-vis March 2010. The largely similar nature of the heating rate profiles during March 2010 and April 2011 highlights the average features of the heating rate profile during summer months over the region of study. Thus, during the summer months the study region is characterised by maxima in the heating rates $\left(\sim 5 \mathrm{~K} \mathrm{day}^{-1}\right)$ at around $4-5 \mathrm{~km}$, while during the winter months the maxima $\left(\sim 1 \mathrm{~K} \mathrm{day}^{-1}\right)$ are near the surface.

\subsubsection{Atmospheric heating rates due to modelled BC}

The corresponding atmospheric heating rate profiles in the model simulations are shown in Fig. 9d, e and f. The heating rates are computed for the corresponding $\mathrm{BC}$ profiles (ACEM) shown in Fig. 2g, h and i (red line). The profiles are representative of all such profiles which show the effect of aircraft emissions. During March 2010, the model heating rate profile (Fig. 9d) shows similar features vis-à-vis the corresponding observations (Fig. 9a). Though the actual magnitudes of the heating rates are lower for the model-simulated profiles, the model captures the major and important features, such as a steady increase in heating rates from the surface to $3 \mathrm{~km}$ and maxima in heating rates at around $3-4 \mathrm{~km}$. Interestingly, a secondary peak in heating rates can be seen around $11 \mathrm{~km}$. This peak corresponds to the peak in BC as seen in Fig. 2g (red line). During January 2011 (Fig. 9e), the model also shows high values of heating rates nearer to the surface and similar to the observations (Fig. 9b). Beyond this height, the heating rates decrease. A secondary peak in heating rates at around $10-12 \mathrm{~km}$ is also seen during January 2011 with a magnitude as high as $0.5 \mathrm{~K} \mathrm{day}^{-1}$. During April 2011, the model heating rate profile (Fig. 9f) shows a maximum close to the surface corresponding to the maximum in BC (red line, Fig. 2i) and multiple maxima at higher heights $(3$ and $6 \mathrm{~km})$ corresponding to the presence of $\mathrm{BC}$ layers. The upper level maximum at around $11 \mathrm{~km}$ is seen to be relatively weaker during April (Fig. 9f) vis-à-vis March (Fig. 9d) and January (Fig. 9e) simulations. The heating rate profiles shown in Fig. 9d-f are representative of all locations which show aircraft-emitted BC trails at higher altitudes but are located away from the areas with high emission intensity (the areas with higher aircraft $\mathrm{BC}$ emission intensity are the regions where two or more aircraft-emitted trails cross each other, which results in higher emission intensity over those regions compared to other regions with emitted trails). We term these generic heating rate profiles as "normal profiles". Additionally, we inspected the heating rate profiles for locations within the trail in the vicinity of the areas with relatively high emission intensity. We term the corresponding heating rate profiles as "extreme profiles". Such extreme profiles of heating rates are shown in Fig. 9g-i for March 2010, Jan- 
uary 2011 and April 2011 respectively. It can be noticed from Fig. $9 \mathrm{~d}-\mathrm{i}$ that while the extreme profiles show similar heating rate magnitudes within the lower part of the atmosphere as those of the normal profiles, they produce very high heating rates at higher heights $(10-12 \mathrm{~km})$. Such heating rates even cross the near-surface maxima for the April 2011 profile (Fig. 9i). The rarer atmosphere could also contribute to such high values of heating rates at those altitudes as seen from Eq. (2). Such large heating rate values at those heights can affect the stability of the atmosphere. The resulting vertical mixing can lift the $\mathrm{BC}$ particles even higher. This continuous warming-lifting cycle can result in the further vertical transport of BC particulate, which is termed as the self-lifting of BC (de Laat et al., 2012). In addition to the self-lifting mechanism, the $\mathrm{BC}$ emitted at high altitudes can be transported vertically in presence of strong underlying convection. In the next section, with the help of model simulations, we show that such convective transport of high-altitude BC could occur in the tropics during periods of strong convection.

\subsection{Convective lifting of $\mathrm{BC}$}

To examine the convective lifting of high-altitude $\mathrm{BC}$, we have carried out WRF-Chem simulations with and without the prescription of aircraft BC emissions (ACEM and NoACEM respectively) over the Indian region for a period of 1 week covering strong convective activity over the model domain during July 2010. July was selected for this purpose in view of the known prevalence of deep convection over the Indian region associated with the summer monsoon and the TTL being thinnest at this time of the year (Meenu et al., 2010; Sunilkumar et al., 2013). The animation (Mov. 1 in the Supplement) shows height-longitude plots of the maximum value of $\mathrm{BC}$ for a latitude belt of $2.25^{\circ}$ over Hyderabad (the $X$ axis is longitude, and the $Y$ axis is height in metres) in the ACEM case. The animation clearly reveals the capability of strong convection to lift $\mathrm{BC}$ to heights beyond $14 \mathrm{~km}$. On a few occasions, these layers are seen to be transported even beyond $17 \mathrm{~km}$ across the tropopause. Similarly, we compute the difference in the upper tropospheric BC mass concentration values in ACEM simulations vis-à-vis the NoACEM case $\left(\triangle B C=B C_{A C E M}-B C_{\text {NoACEM }}\right)$ averaged for the entire duration of the model simulations carried out during July 2010 . The maximum of such time-averaged $\triangle B C$ values across the latitude belt of $2.25^{\circ}$ centred over Hyderabad for every longitude of the model domain is shown in Fig. 10. The time-averaged increment in UTLS (upper troposphere and lower stratosphere) BC load due to aircraft BC emissions is seen to occur over the entire longitude belt, though it is more pronounced over a few longitude bands $\left(79-80^{\circ} \mathrm{E}\right)$. Higher $\triangle \mathrm{BC}$ values extend vertically even beyond $17.6 \mathrm{~km}$, highlighting the mean vertical transport of aircraft-emitted $\mathrm{BC}$ in the UTLS region. This provides strong evidence for the intrusion of high-altitude aircraft-emitted BC into the upper tropospheric and lower stratospheric heights over the In-

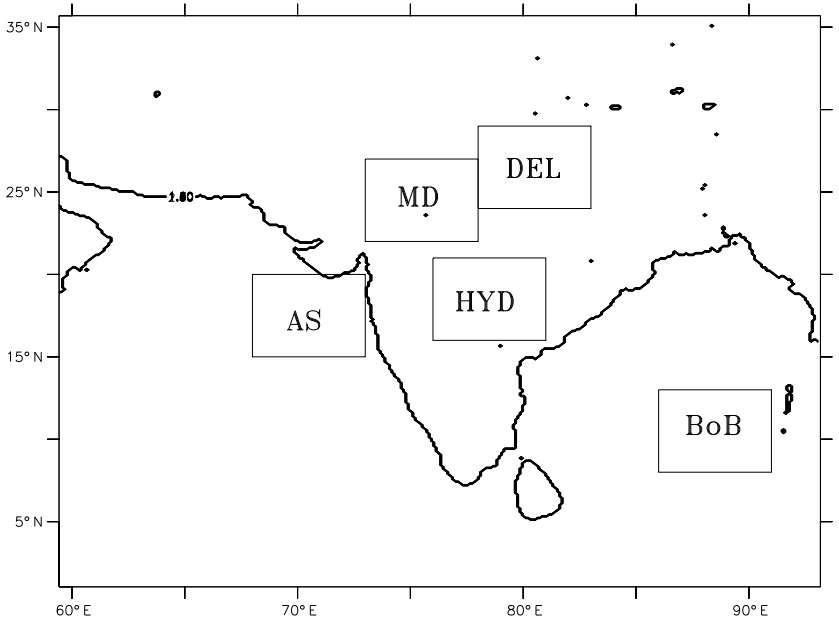

Figure 11. The $5^{\circ} \times 5^{\circ}$ regional boxes considered for the CALIPSO analysis (AS is the Arabian Sea, BoB is the Bay of Bengal, HYD is Hyderabad, MD is Mumbai and Delhi and DEL is Delhi).

dian region during strong convective periods. The intrusion of such tropospheric air into the stratosphere will be favoured under certain conditions like a thinner tropopause layer or unstable conditions within the tropopause layer. In the next section, we show observations supporting such intrusion.

\subsection{Occurrence of $\mathrm{BC}$ at high altitudes: observational evidence}

There are several observational reports of the presence of $\mathrm{BC}$ at upper tropospheric and stratospheric altitudes (Chuan and Woods, 1984; Okada et al., 1992; Pusechel et al., 1992; Pueschel et al., 1997; Sheridan et al., 1994; Blake and Kato, 1995; Strawa et al., 1999; Baumgardner et al., 2004; Schwarz et al., 2006; Kremser et al., 2016). One way to ascertain the occurrence of such layers in the stratosphere is to examine the CALIOP Lidar (on-board the CALIPSO satellite) extinction coefficient data (at $550 \mathrm{~nm}$ ). We have examined all such vertical profiles for 3 consecutive years (from January 2010 to December 2012) over five specifically chosen regions $\left(5^{\circ} \times 5^{\circ}\right)$ over and around India (Fig. 11). Since we want to focus on the presence of aerosols at stratospheric altitudes, we have plotted the vertical profiles of extinction coefficients in the stratospheric altitudes (i.e. from altitudes of 20 to $\sim 30 \mathrm{~km}$ ). The results are shown in Fig. 12.

To our surprise, we notice that the aerosol extinction coefficient values over the stratospheric altitudes are more than $0.02 \mathrm{~km}^{-1}$ over all these regions, and occasionally values greater than $0.06 \mathrm{~km}^{-1}$ are also noticeable (Fig. 12a). The corresponding appended time series of stratospheric (i.e. from altitudes of 20 to $\sim 30 \mathrm{~km}$ ) aerosol optical depth over the regional boxes under consideration from 2010 to 2012 is plotted in Fig. 12b. The AODs are seen to be higher than 0.01 on most of the occasions with frequent spikes reaching 


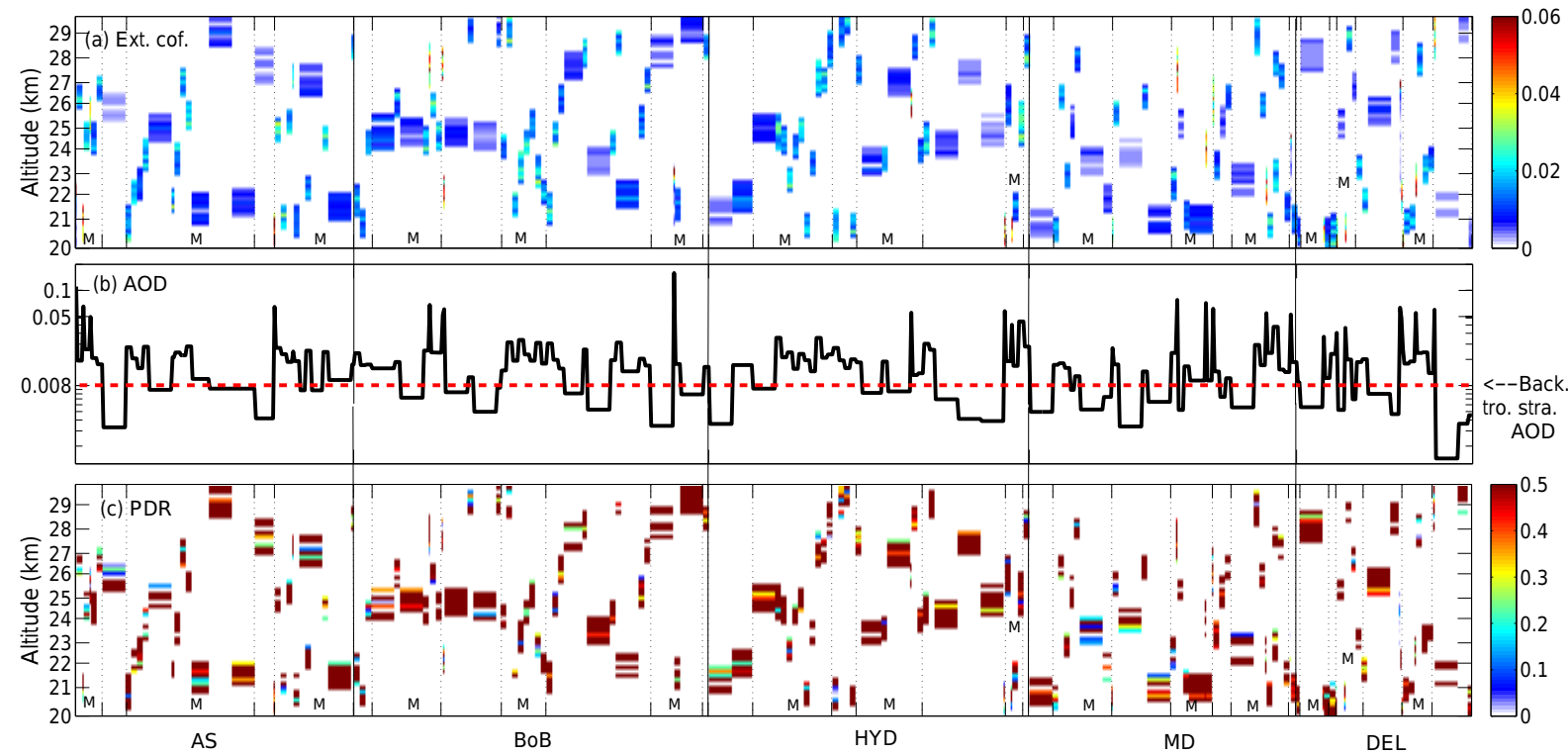

Figure 12. Time series of the vertical profile of the (a) extinction coefficient over five regions (AS is the Arabian Sea, BoB is the Bay of Bengal, HYD is Hyderabad, MD is Mumbai and Delhi and DEL is Delhi) over and around India (b). Corresponding stratospheric (from 20 to $\sim 30 \mathrm{~km}$ ) AOD; the background stratospheric AOD for the entire tropical belt (Kremser et al., 2016) is shown by the dotted red line (c). Particle depolarisation ratio (PDR) over the same five regions from January 2010 to December 2012. The individual time series of the extinction coefficient, AOD and PDR of each region are appended together in the figure one after the other. The letter M signifies the monsoon (JJAS) season during the year under consideration.

as high as 0.16 . We considered different scenarios to explain such high AOD. These included (i) volcanic perturbation to stratospheric AOD and (ii) high-altitude cirrus clouds at the TTL region. We first compared these extinction coefficient and AOD values with the corresponding area-averaged values for the entire tropical belt $\left(20^{\circ} \mathrm{S}\right.$ to $20^{\circ} \mathrm{N}$; Kremser et al., 2016). The maximum value of stratospheric AOD averaged for the entire tropical belt (Kremser et al., 2016) for the period 2010 to 2012 (which is considered to be the background tropical stratospheric AOD in this study) is marked with the dotted red line in Fig. 12b. It can be seen that the stratospheric AODs from our analysis over the five regional boxes are roughly 4-6 times higher than the background tropical stratospheric AOD (dotted red line, Fig. 12b); the same is the case for aerosol extinction coefficient values as well (comparison not shown). The large differences in the background tropical stratospheric AOD and the stratospheric AODs over the Indian region signify an enhancement in the stratospheric aerosol burden over the regions under consideration above the background stratospheric aerosol loading. One of the major controllers of stratospheric AOD is the influx of particulate, namely sulfates, organics and ash, and gases like $\mathrm{SO}_{2}$ from volcanic eruptions into the stratosphere (Kremser et al., 2016). An examination of the occurrence of global volcanic eruptions from 2008 to 2012 (Kremser et al., 2016) suggests that of the 11 major volcanic eruptions that occurred during that period, 7 were centred away from the tropics. Also, the flux of $\mathrm{SO}_{2}$ in the stratosphere from the most intense of the
11 events was merely one-tenth that of the Mount Pinatubo eruption (Kremser et al., 2016). This suggests that the enhancement in AOD and the extinction coefficient over the regions under consideration in this study may not be linked to volcanic eruptions. The monsoon season (June to September; denoted by the letter M in Fig. 12) appears to be the favourite period for the lifted layers in the stratosphere (Fig. 12a). This looks to be linked to the vertical lifting associated with severe convection (as seen in our model simulations; Fig. 10 and Mov. 1 in the Supplement) and thin TTL as explained earlier (Fu et al., 2006; Randel et al., 2010; Vernier et al., 2011; Thampi et al., 2012; Uma et al., 2012). Additionally, these layers seem to be present during the other seasons (premonsoon and winter) as well. The Indian region experiences a large-scale ascending motion above $10 \mathrm{~km}$ during winter months (Rao et al., 2008). Such an ascending motion can cause the intrusion of tropospheric air (lying at $8-10 \mathrm{~km}$ ) into the stratosphere (Rao et al., 2008). Thus, while the monsoonal convection and the related thermodynamics appear to be a cause of the summertime higher extinction coefficient values at stratospheric heights over the Indian region, the transport of tropospheric air mass into the stratosphere due to the large-scale ascent beyond $10 \mathrm{~km}$ looks to be responsible for the wintertime high values.

To shed light on the aerosol species responsible for such extinction coefficient values, we examined the particle depolarisation ratios (at $550 \mathrm{~nm}$; henceforth PDRs) at these altitudes (Fig. 12c). The PDR is the ratio of the attenuated 
backscatter coefficient in the perpendicular polarisation to that in the parallel polarisation. We computed the PDR values from the corresponding backscatter coefficient values. The PDR values are seen to be higher than 0.3 on most occasions. This suggests the presence of non-spherical aerosol species at those altitudes. One of the major non-spherical aerosol species over this region is mineral dust. The source of mineral dust aerosol species in the stratosphere could be largely related to (a) volcanic eruptions, (b) meteoritic debris and (c) the convective transport of tropospheric dust. As mentioned previously, our study has been carried out for a period which is relatively volcanically quiescent. Thus, volcanically erupted dust may not have contributed much to the stratospheric aerosol burden during our study period. Meteoritic debris forms a minor part (5-10\%) of the stratospheric aerosol composition, especially at altitudes lower than $30 \mathrm{~km}$ (Turco et al., 1981), making it difficult to capture with a lidar. Moreover, meteoritic debris is reported to be coarse in size (i.e. having a radius larger than $1 \mu \mathrm{m}$; Turco et al., 1981; Mackinnon et al., 1982) and hence would have large deposition rates and be largely spherical in shape (Mackinnon et al., 1982 ) with lower values of particle depolarisation ratio (PDR less than 0.1; Klekociuk et al., 2005). The extinction coefficients associated with plumes of meteoritic debris are 3 orders of magnitude less (Gorkavyi et al., 2013) than the values we notice over our study domain. These points together rule out the possibility of associating the observed values of extinction coefficients and PDRs with meteoritic dust. The convectively lifted dust and other air pollutants can move into the higher altitude regime (Andreae et al., 2001; Randel et al., 2010; Vernier et al., 2011; Fadnavis et al., 2013; Corr et al., 2016), but their transport over the Indian region is limited to around $20 \mathrm{~km}$ (Fadnavis et al., 2013), which is mainly governed by the height of convective towers (Meenu et al., 2010). Moreover, dust aerosol is 2.6 times heavier than BC (Hess et al., 1998) and also less solar absorbent; thus it is unlikely to be vertically lifted beyond $20 \mathrm{~km}$ by large-scale or self-lifting mechanisms (de Laat et al., 2012). Hence we eliminate the possibility of tropospheric dust existing beyond $22 \mathrm{~km}$ of altitude over our domain. Additionally, the maximum cloud top altitude occurring over the Indian region during the monsoon season is $20 \mathrm{~km}$ (Meenu et al., 2010). This suggests that the non-spherical ice crystals emanating from the anvils of the convective towers over the Indian region can be found only around $20 \mathrm{~km}$ and not above $21-22 \mathrm{~km}$. This eliminates the possibility of the presence of non-spherical mineral dust particles and ice crystals at these heights. A few previous studies have noticed the presence of BC chain agglomerates at the upper tropospheric and lower stratospheric heights (Blake and Kato, 1995; Bekki, 1997). Such transport of BC to the stratospheric heights could be the result of convective lifting (as seen in our model simulations; Fig. 10 and Mov. 1) and the self-lifting (de Laat et al., 2012) associated with it. Though pure and nascent $\mathrm{BC}$ has a relatively lower value of PDR, aged BC particles are porous (Chand et al., 2005; Dusek et al., 2005) and capable of forming long chain agglomerates that are non-spherical and would depict higher values of PDR. Such BC agglomerates, even when mixed with stratospheric sulfate, could still give rise to nonspherical shapes and thus higher values of PDR. This indicates the possible existence of $\mathrm{BC}$ at the stratospheric altitudes over the Indian region. Thus, the model-simulated convective transport of high-altitude aircraft-emitted BC layers to the UTLS region combined with favourable conditions for cross-tropopause transport of air mass over the Indian region during monsoonal months, large-scale wintertime ascending motion above $10 \mathrm{~km}$ over the Indian region and the presence of local BC emission sources (aircraft) at high altitudes $(\sim 10 \mathrm{~km})$ throughout the year together indicate the possibility of aircraft emissions being primarily responsible for the possible presence of $\mathrm{BC}$ in the stratosphere over the Indian region.

\section{Possible implications of $\mathrm{BC}$ presence at stratospheric heights}

Our model simulations suggest that aircraft emissions are capable of producing the observed elevated aerosol layers in the free troposphere (middle and upper), and the BC particles in these layers can intrude into the stratosphere, especially during periods of thin TTL, aided by strong convective lofting (associated with the summer monsoon) and self-lifting mechanisms. The average residence time of stratospheric aerosol is about 1 year (Snetsinger et al., 1987). BC aerosols, owing to their porosity and fractal shape (Blake and Kato, 1995; Bekki, 1997), can provide a larger surface area to support heterogeneous chemical reactions in the upper troposphere and lower stratosphere. One such reaction is the ozone decomposition on BC (Akhter et al., 1985; Bekki, 1997; Schurath and Naumann, 1998; Disselkamp et al., 2000; Chughtai et al., 2003; Satheesh et al., 2013), which may result in the depletion of stratospheric ozone. If $\mathrm{BC}$ is transported to the stratospheric heights, the high-altitude cirrus clouds around the TTL, which reflect back most of the solar radiation incident on them, would consequently induce increased interaction between solar radiation and the lifted BC layer (Satheesh and Moorthy, 2005). This would substantially enhance the $\mathrm{BC}$-induced warming of the lower stratosphere. Since the atmosphere becomes increasingly thinner with altitude, for a given amount of absorbed energy, the warming would be higher at upper levels than near the surface. Based on laboratory experiments, Kamm et al. (1999) have reported that the reaction rate of loss of ozone in the presence of $\mathrm{BC}$ has a positive temperature dependence. Thus, the aircraft-emitted BC could possibly contribute to the depletion of the stratospheric ozone layer. The continued negative trend in stratospheric ozone over $40^{\circ} \mathrm{S}-40^{\circ} \mathrm{N}$ from 1984 to 2014 (Bourassa et al., 2014) could possibly be related to everincreasing aircraft traffic (Paraschis and Gittens, 2014; Pic- 
colo and Gittens, 2015, 2016). The observed delays in the recovery of the stratospheric ozone hole (Kane, 2008, 2009) could also be influenced by such interactions of lifted BC with stratospheric ozone.

With the help of a regional chemistry transport model, our study showed that aircraft (with emissions from the regionally fine-tuned MACCity inventory) appear to be one of the primary causes behind the occurrence of the sharp elevated layers of $\mathrm{BC}$ over the Indian region. This study utilised high-altitude measurements of $\mathrm{BC}$ carried out using a zeropressure balloon. Though the balloon measurements were carried out in three different seasons to capture the seasonal picture, they are limited in number. In future, more of such high-altitude balloon measurements of $\mathrm{BC}$ would be needed to confirm the persistence of such elevated sharp BC peaks. Also, though the high-altitude balloon launching facility is currently available only at one station in India, more of such balloon measurements from different locations using mobile facilities would be useful to generalise the results. Additionally, such high-altitude BC measurements could also be carried out in the vicinity of busier airport locations across the world to shed more light on such implications of aircraft emissions. The BC emissions from aircraft in the MACCity inventory were scaled in this study with necessary modifications. This highlights the large uncertainty associated with $\mathrm{BC}$ emissions from aircraft, especially regarding the emission factor for $\mathrm{BC}(\mathrm{EI}(\mathrm{BC}))$ and possibly actual air traffic data. This uncertainty needs to be examined in future to constrain the implications of emissions from aircraft.

\section{Conclusions}

The altitude distribution of $\mathrm{BC}$ in the atmosphere plays a crucial role in deciding the BC-induced warming of the atmosphere. Such an atmospheric warming due to $\mathrm{BC}$ is amplified when $\mathrm{BC}$ is above strongly reflective surfaces like clouds. The enhanced warming of $\mathrm{BC}$ can give rise to local instability and subsequent vertical lifting. Such an absorptionwarming-convection cycle can transport $\mathrm{BC}$ to higher altitudes. On account of its absorbing nature, high-altitude BC can burn off cirrus clouds. Realising the importance of the vertical profile of BC, Babu et al. (2011) measured the vertical profile of $\mathrm{BC}$ over the strongly convecting Indian region during pre-monsoon periods (March 2010) using a high-altitude zero-pressure balloon. The authors reported two sharp and confined high-altitude layers of BC at 4.5 and $8.3 \mathrm{~km}$. The existence of the high-altitude BC layers was confirmed by two subsequent balloon flights conducted during the following winter and pre-monsoon seasons. While the high values of $\mathrm{BC}$ within the first $3 \mathrm{~km}$ of the atmosphere could be explained by boundary layer mixing, the higher $\mathrm{BC}$ values aloft appeared to be a mystery. The present study used the regional chemistry transport model, WRF-Chem, to understand the causes behind the observed high-altitude sharp and confined BC layers. Firstly, the simulations (incorporating surface $\mathrm{BC}$ emissions only) of the meteorological parameters within the model were examined. Broad agreement of the model-simulated meteorological variables with their corresponding observations from the balloon measurements was found. The model-simulated vertical profiles of BC were compared with the corresponding observed profile, but it was found that the model could not replicate the high-altitude BC layers as seen in observations. Thus, reasonable simulations of meteorology within the model could not give rise to the high-altitude BC layers. The emission of $\mathrm{BC}$ from high-altitude sources, i.e. aircraft, was prescribed in our simulations. The aircraft $\mathrm{BC}$ emissions from the MACCity inventory, interpolated to our model grids with necessary modifications, were used for this purpose. Upon the prescription of aircraft $\mathrm{BC}$ emissions from the regionally fine-tuned MACCity inventory, the model-simulated vertical profile of $\mathrm{BC}$ started showing the mysterious high-altitude BC peaks as seen in the observations. The sharp and confined nature of the simulated BC peaks showed large similarities with the observations, though their exact altitude and magnitude differed vis-à-vis the observations. The major role played by $\mathrm{BC}$ emissions from aircraft in causing high-altitude BC peaks was reconfirmed when the peaks remained undisturbed, even after shutting down the surface level emissions of BC. The probability of the occurrence of such high-altitude (9-11 km) BC peaks was found to be more than $40 \%$ over many locations within the model domain during all the seasons except the monsoon. During the monsoon season, the strong convection mixes $\mathrm{BC}$ throughout the atmospheric column, resulting in the removal of such elevated sharp peaks.

The corresponding atmospheric heating rates due to such observed and simulated profiles of $\mathrm{BC}$ were then computed. It was seen that such $\mathrm{BC}$ profiles could give rise to local instability and subsequent vertical mixing even at higher altitudes $(\sim 10-11 \mathrm{~km})$. Such high-altitude BC peaks would cause warming, which could be amplified in the presence of highly reflective clouds beneath them. This absorptionwarming-convection cycle could possibly lift BC to even higher altitudes. In addition to such self-lifting, it was seen in a separate model simulation done for the monsoonal month of July that such high-altitude BC was transported vertically by the underlying strong convection over the Indian region. The transport was seen to be as high as $17.6 \mathrm{~km}$, i.e. the UTLS region. Many previous studies have reported that the near-tropopause conditions over the Indian region, especially during monsoonal months, are more favourable for the crosstropopause transport of the tropospheric air mass. This could act as a pathway for the lifted aircraft-emitted BC layers to reach the stratosphere. Many previous studies have also reported the presence of $\mathrm{BC}$ in the stratosphere. To understand this further, the vertical profiles of aerosol extinction coefficients from satellite measurements over the stratospheric heights across the Indian region were examined. Extinction coefficient values as high as $0.02 \mathrm{~km}^{-1}$, which were an or- 
der of magnitude greater than the average tropical stratospheric aerosol extinction coefficients, were noticed. Though such layers were more visible during the monsoonal months, their presence during winters hinted at the possible cooperation between self-lifting and large-scale ascent over Indian region in bringing the layers into the UTLS region. On the further examination, it was found that the particle depolarisation ratio corresponding to the high-value extinction coefficients was higher than 0.3 . Such high values of PDR signify the non-spherical nature of the involved species. Eliminating the possibility of mineral dust particles and ice crystals being responsible for such high values of PDR and considering the findings from previous studies on the presence of non-spherical BC chain agglomerates in the UTLS region, it was concluded that such BC structures could possibly be responsible for the high values of PDR over the stratospheric altitudes. Once in the stratosphere, $\mathrm{BC}$ can reside for a longer period of time due to the inherent stability of the stratosphere and the absence of strong removal mechanisms. One of the possible implications of the presence of $\mathrm{BC}$ in the stratosphere is a reaction involving the decomposition of ozone on $\mathrm{BC}$, which would result in the depletion of ozone. Potentially, the lifted upper tropospheric BC in the stratosphere could harm the earth's protective blanket. Thus, while aircraft look to be the cause of the sharp and confined high-altitude layers of BC, such layers when lifted to the stratosphere (under favourable conditions) can potentially affect the ozone layer and have significant implications for the health of all living organisms. Realising the potential impact of emissions from aircraft, a recent article (Editorial, 2016) also advocates for regulations on aircraft emissions. More observational studies using satellite and stratospheric balloons and modelling studies are required to address this important phenomenon, especially over regions of high aircraft activity.

Code availability. The simulations were performed using an opensource online regional chemistry transport model, WRF-Chem, which is freely available at http://www2.mmm.ucar.edu/wrf/users/.

Data availability. The extinction coefficient level 2 data from CALIPSO are available freely at https://eosweb.larc.nasa.gov/ HBDOCS/langley_web_tool.html.

The Supplement related to this article is available online at https://doi.org/10.5194/acp-17-9623-2017-supplement.

Competing interests. The authors declare that they have no conflict of interest.
Acknowledgements. All the computations are conducted on the computational cluster funded jointly by the Department of Science and Technology FIST program (DST-FIST), the Divecha Centre for Climate Change and the ARFI project of the Indian Space Research Organisation (ISRO). This work is partially supported by MoES (grant no. MM/NERC-MoES-1/2014/002) under the South West Asian Aerosol Monsoon Interactions (SWAAMI) project. We thank the anonymous reviewers for the detailed evaluation and useful suggestions. We would also like to thank the Computational and Information Systems Laboratory (CISL-NCAR) for the Research Data Archive.

Edited by: Toshihiko Takemura

Reviewed by: two anonymous referees

\section{References}

Ackerman, A. S., Toon, O. B., Stevens, D. E., Heymsfield, A. J., Ramanathan, V., and Welton, E. J.: Reduction of Tropical Cloudiness by Soot, Science, 288, 1042-1047, https://doi.org/10.1126/science.288.5468.1042, 2000.

Akhter, M. S., Chughtai, A. R., and Smith, D. M.: The Structure of Hexane Soot I: Spectroscopic Studies, Appl. Spectrosc., 39, 143-153, https://doi.org/10.1366/0003702854249114, 1985.

Andreae, M. O., Artaxo, P., Fischer, H., Freitas, S. R., Grégoire, J.-M., Hansel, A., Hoor, P., Kormann, R., Krejci, R., Lange, L., Lelieveld, J., Lindinger, W., Longo, K., Peters, W., de Reus, M., Scheeren, B., Silva Dias, M. A. F., Ström, J., van Velthoven, P. F. J., and Williams, J.: Transport of biomass burning smoke to the upper troposphere by deep convection in the equatorial region, Geophys. Res. Lett., 28, 951-954, https://doi.org/10.1029/2000GL012391, 2001.

Arkoudeas, P., Kalligeros, S., Zannikos, F., Anastopoulos, G., Karonis, D., Korres, D., and Lois, E.: Study of using JP-8 aviation fuel and biodiesel in $\{\mathrm{CI}\}$ engines, Energ. Convers. Manage., 44, 1013-1025, https://doi.org/10.1016/S0196-8904(02)001127, 2003.

Arnott, W. P., Hamasha, K., Moosmüller, H., Sheridan, P. J., and Ogren, J. A.: Towards Aerosol Light-Absorption Measurements with a 7-Wavelength Aethalometer: Evaluation with a Photoacoustic Instrument and 3Wavelength Nephelometer, Aerosol Sci. Tech., 39, 17-29, https://doi.org/10.1080/027868290901972, 2005.

Babu, S. S., Satheesh, S. K., and Moorthy, K. K.: Aerosol radiative forcing due to enhanced black carbon at an urban site in India, Geophys. Res. Lett., 29, 1880, https://doi.org/10.1029/2002GL015826, 2002.

Babu, S. S., Satheesh, S. K., Moorthy, K. K., Dutt, C. B. S., Nair, V. S., Alappattu, D. P., and Kunhikrishnan, P. K.: Aircraft measurements of aerosol black carbon from a coastal location in the north-east part of peninsular India during ICARB, J. Earth Syst. Sci., 117, 263-271, https://doi.org/10.1007/s12040-008-0030-1, 2008.

Babu, S. S., Moorthy, K., and Satheesh, S.: Vertical and Horizontal Gradients in Aerosol Black Carbon and Its Mass Fraction to Composite Aerosols over the East Coast of Peninsular India from Aircraft Measurements, Adv. Meteorol., 2010, 812075, https://doi.org/10.1155/2010/812075, 2010. 
Babu, S. S., Moorthy, K. K., Manchanda, R. K., Sinha, P. R., Satheesh, S. K., Vajja, D. P., Srinivasan, S., and Kumar, V. H. A.: Free tropospheric black carbon aerosol measurements using high altitude balloon: Do BC layers build "their own homes" up in the atmosphere?, Geophys. Res. Lett., 38, L08803, https://doi.org/10.1029/2011GL046654, 2011.

Baumgardner, D., Kok, G., and Raga, G.: Warming of the Arctic lower stratosphere by light absorbing particles, Geophys. Res. Lett., 31, L06117, https://doi.org/10.1029/2003GL018883, 2004.

Bekki, S.: On the possible role of aircraft-generated soot in the middle latitude ozone depletion, J. Geophys. Res.-Atmos., 102, 10751-10758, https://doi.org/10.1029/97JD00134, 1997.

Blake, D. F. and Kato, K.: Latitudinal distribution of black carbon soot in the upper troposphere and lower stratosphere, J. Geophys. Res.-Atmos., 100, 7195-7202, https://doi.org/10.1029/94JD03118, 1995.

Blakey, S., Rye, L., and Wilson, C. W.: Aviation gas turbine alternative fuels: A review, P. Combust. Inst., 33, 2863-2885, https://doi.org/10.1016/j.proci.2010.09.011, 2011.

Bond, T. C., Doherty, S. J., Fahey, D. W., Forster, P. M., Berntsen, T., DeAngelo, B. J., Flanner, M. G., Ghan, S., Kärcher, B., Koch, D., Kinne, S., Kondo, Y., Quinn, P. K., Sarofim, M. C., Schultz, M. G., Schulz, M., Venkataraman, C., Zhang, H., Zhang, S., Bellouin, N., Guttikunda, S. K., Hopke, P. K., Jacobson, M. Z., Kaiser, J. W., Klimont, Z., Lohmann, U., Schwarz, J. P., Shindell, D., Storelvmo, T., Warren, S. G., and Zender, C. S.: Bounding the role of black carbon in the climate system: A scientific assessment, J. Geophys. Res.-Atmos., 118, 5380-5552, https://doi.org/10.1002/jgrd.50171, 2013.

Boucher, O., Randall, D., Artaxo, P., Bretherton, C., Feingold, G., Forster, P., Kerminen, V.-M., Y. Kondo Y., Liao, H., Lohmann, U., Rasch, P., Satheesh, S. K., Sherwood, S., Stevens, B., and Zhang, X. Y.: Clouds and Aerosols, in: Climate Change 2013: The Physical Science Basis. Contribution of Working Group I to the Fifth Assessment Report of the Intergovernmental Panel on Climate Change, edited by: Stocker, T. F., Qin, D., Plattner, G.K., Tignor, M., Allen, S. K., Boschung, J., Nauels, A., Xia, Y., Bex, V., and Midgley, P. M., Cambridge University Press, Cambridge, United Kingdom and New York, NY, USA, 571-658, https://doi.org/10.1017/CBO9781107415324.016, 2013.

Bourassa, A. E., Degenstein, D. A., Randel, W. J., Zawodny, J. M., Kyrölä, E., McLinden, C. A., Sioris, C. E., and Roth, C. Z.: Trends in stratospheric ozone derived from merged SAGE II and Odin-OSIRIS satellite observations, Atmos. Chem. Phys., 14, 6983-6994, https://doi.org/10.5194/acp-14-6983-2014, 2014.

CALIPSO: The extinction coefficient level 2 data, https://eosweb. larc.nasa.gov/HBDOCS/langley_web_tool.html, last access: 8 August 2017.

Chakraborty, A., Satheesh, S. K., Nanjundiah, R. S., and Srinivasan, J.: Impact of absorbing aerosols on the simulation of climate over the Indian region in an atmospheric general circulation model, Ann. Geophys., 22, 1421-1434, https://doi.org/10.5194/angeo22-1421-2004, 2004.

Chand, D., Schmid, O., Gwaze, P., Parmar, R. S., Helas, G., Zeromskiene, K., Wiedensohler, A., Massling, A., and Andreae, M. O.: Laboratory measurements of smoke optical properties from the burning of Indonesian peat and other types of biomass, Geophys. Res. Lett., 32, L12819, https://doi.org/10.1029/2005GL022678, 2005.
Chand, D., Wood, R., Anderson, T. L., Satheesh, S. K., and Charlson, R. J.: Satellite-derived direct radiative effect of aerosols dependent on cloud cover, Nat. Geosci., 2, 181-184, https://doi.org/10.1038/ngeo437, 2009.

Chin, M., Ginoux, P., Kinne, S., Torres, O., Holben, B. N., Duncan, B. N., Martin, R. V., Logan, J. A., Higurashi, A., and Nakajima, T.: Tropospheric aerosol optical thickness from the GOCART model and comparisons with satellite and Sun photometer measurements, J. Atmos. Sci., 59, 461-483, 2002.

Chuan, R. L. and Woods, D. C.: The appearance of carbon aerosol oarticles in the lower stratosphere, Geophys. Res. Lett., 11, 553556, https://doi.org/10.1029/GL011i005p00553, 1984.

Chughtai, A. R., Kim, J. M., and Smith, D. M.: The Effect of Temperature and Humidity on the Reaction of Ozone with Combustion Soot: Implications for Reactivity near the Tropopause, J. Atmos. Chem., 45, 231-243, https://doi.org/10.1023/A:1024250505886, 2003.

Cookson, D. J. and Smith, B. E.: Calculation of jet and diesel fuel properties using carbon-13 NMR spectroscopy, Energ. Fuel., 4, 152-156, https://doi.org/10.1021/ef00020a004, 1990.

Corr, C. A., Ziemba, L. D., Scheuer, E., Anderson, B. E., Beyersdorf, A. J., Chen, G., Crosbie, E., Moore, R. H., Shook, M., Thornhill, K. L., Winstead, E., Lawson, R. P., Barth, M. C., Schroeder, J. R., Blake, D. R., and Dibb, J. E.: Observational evidence for the convective transport of dust over the Central United States, J. Geophys. Res.-Atmos., 121, 1306-1319, https://doi.org/10.1002/2015JD023789, 2016.

Corrigan, C. E., Ramanathan, V., and Schauer, J. J.: Impact of monsoon transitions on the physical and optical properties of aerosols, J. Geophys. Res.-Atmos., 111, D18208, https://doi.org/10.1029/2005JD006370, 2006.

Das, S. S., Venkat Ratnam, M., Uma, K. N., Patra, A. K., Subrahmanyam, K. V., Girach, I. A., Suneeth, K. V., Kumar, K. K., and Ramkumar, G.: Stratospheric intrusion into the troposphere during the tropical cyclone Nilam (2012), Q. J. Roy. Meteor. Soc., 142, 2168-2179, 2016.

de Laat, A. T. J., Stein Zweers, D. C., Boers, R., and Tuinder, O. N. E.: A solar escalator: Observational evidence of the self-lifting of smoke and aerosols by absorption of solar radiation in the February 2009 Australian Black Saturday plume, J. Geophys. Res.-Atmos., 117, D04204, https://doi.org/10.1029/2011JD017016, 2012.

Disselkamp, R. S., Carpenter, M. A., Cowin, J. P., Berkowitz, C. M., Chapman, E. G., Zaveri, R. A., and Laulainen, N. S.: Ozone loss in soot aerosols, J. Geophys. Res.-Atmos., 105, 9767-9771, https://doi.org/10.1029/1999JD901189, 2000.

Dudhia, J.: Numerical Study of Convection Observed during the Winter Monsoon Experiment Using a Mesoscale TwoDimensional Model, J. Atmos. Sci., 105, 3077-3107, 1989.

Dusek, U., Frank, G. P., Helas, G., Iinuma, Y., Zeromskiene, K., Gwaze, P., Hennig, T., Massling, A., Schmid, O., Herrmann, H., Wiedensohler, A., and Andreae, M. O.: "Missing" cloud condensation nuclei in peat smoke, Geophys. Res. Lett., 32, L11802, https://doi.org/10.1029/2005GL022473, 2005.

Editorial: Green-sky thinking, Nature, 530, 253-253, https://doi.org/10.1038/530253a, 2016.

Emmons, L. K., Walters, S., Hess, P. G., Lamarque, J.-F., Pfister, G. G., Fillmore, D., Granier, C., Guenther, A., Kinnison, D., Laepple, T., Orlando, J., Tie, X., Tyndall, G., Wiedinmyer, 
C., Baughcum, S. L., and Kloster, S.: Description and evaluation of the Model for Ozone and Related chemical Tracers, version 4 (MOZART-4), Geosci. Model Dev., 3, 43-67, https://doi.org/10.5194/gmd-3-43-2010, 2010.

Fadnavis, S., Semeniuk, K., Pozzoli, L., Schultz, M. G., Ghude, S. D., Das, S., and Kakatkar, R.: Transport of aerosols into the UTLS and their impact on the Asian monsoon region as seen in a global model simulation, Atmos. Chem. Phys., 13, 8771-8786, https://doi.org/10.5194/acp-13-8771-2013, 2013.

Fan, J., Zhang, R., Tao, W.-K., and Mohr, K. I.: Effects of aerosol optical properties on deep convective clouds and radiative forcing, J. Geophys. Res.-Atmos., 113, D08209, https://doi.org/10.1029/2007JD009257, 2008.

Freitas, S. R., Longo, K. M., Chatfield, R., Latham, D., Silva Dias, M. A. F., Andreae, M. O., Prins, E., Santos, J. C., Gielow, R., and Carvalho Jr., J. A.: Including the sub-grid scale plume rise of vegetation fires in low resolution atmospheric transport models, Atmos. Chem. Phys., 7, 3385-3398, https://doi.org/10.5194/acp7-3385-2007, 2007.

Freitas, S. R., Longo, K. M., Alonso, M. F., Pirre, M., Marecal, V., Grell, G., Stockler, R., Mello, R. F., and Sánchez Gácita, M.: PREP-CHEM-SRC-1.0: a preprocessor of trace gas and aerosol emission fields for regional and global atmospheric chemistry models, Geosci. Model Dev., 4, 419-433, https://doi.org/10.5194/gmd-4-419-2011, 2011.

Fromm, M., Bevilacqua, R., Servranckx, R., Rosen, J., Thayer, J. P., Herman, J., and Larko, D.: Pyro-cumulonimbus injection of smoke to the stratosphere: Observations and impact of a super blowup in northwestern Canada on 34 August 1998, J. Geophys. Res.-Atmos., 110, D08205, https://doi.org/10.1029/2004JD005350, 2005.

Fu, R., Hu, Y., Wright, J. S., Jiang, J. H., Dickinson, R. E., Chen, M., Filipiak, M., Read,W. G., Waters, J. W., and $\mathrm{Wu}, \mathrm{D}$. L.: Short circuit of water vapor and polluted air to the global stratosphere by convective transport over the Tibetan Plateau, P. Natl. Acad. Sci. USA, 103, 5664-5669, https://doi.org/10.1073/pnas.0601584103, 2006.

Fueglistaler, S., Dessler, A. E., Dunkerton, T. J., Folkins, I., Fu, Q., and Mote, P. W.: Tropical tropopause layer, Rev. Geophys., 47, RG1004, https://doi.org/10.1029/2008RG000267, 2009.

Gautam, R., Hsu, N. C., Lau, W. K.-M., and Yasunari, T. J.: Satellite observations of desert dust-induced Himalayan snow darkening, Geophys. Res. Lett., 40, 988-993, https://doi.org/10.1002/grl.50226, 2013.

Gorkavyi, N., Rault, D. F., Newman, P. A., da Silva, A. M., and Dudorov, A. E.: New stratospheric dust belt due to the Chelyabinsk bolide, Geophys. Res. Lett., 40, 4728-4733, https://doi.org/10.1002/grl.50788, 2013.

Govardhan, G., Nanjundiah, R. S., Satheesh, S. K., Moorthy, K. K., and Kotamarthi, V. R.: Performance of WRF-Chem over Indian region: Comparison with measurements, J. Earth Syst. Sci., 124, 875-896, https://doi.org/10.1007/s12040-015-0576-7, 2015.

Govardhan, G. R., Nanjundiah, R. S., Satheesh, S., Moorthy, K. K., and Takemura, T.: Inter-comparison and performance evaluation of chemistry transport models over Indian region, Atmos. Environ., 125, 486-504, https://doi.org/10.1016/j.atmosenv.2015.10.065, 2016.

Hansen, A.: Magee Scientific Aethalometer User's Guide, Magee Sci., Berkeley, California, 56 pp., 1996.
Hansen, A.: The Aethalometer, Magee Sci., Berkeley, California, 2005.

Haywood, J. M. and Shine, K. P.: The effect of anthropogenic sulfate and soot aerosol on the clear sky planetary radiation budget, Geophys. Res. Lett., 22, 603-606, https://doi.org/10.1029/95GL00075, 1995.

Herndon, S. C., Jayne, J. T., Lobo, P., Onasch, T. B., Fleming, G., Hagen, D. E., Whitefield, P. D., and Miake-Lye, R. C.: Commercial Aircraft Engine Emissions Characterization of in-Use Aircraft at Hartsfield-Jackson Atlanta International Airport, Environ. Sci. Technol., 42, 1877-1883, https://doi.org/10.1021/es072029+, 2008.

Hess, M., Koepke, P., and Schult, I.: Optical Properties of Aerosols and Clouds: The Software Package OPAC, B. Am. Meteorol. Soc., 79, 831-844, https://doi.org/10.1175/15200477(1998)079<0831:OPOAAC>2.0.CO;2, 1998.

Hong, S., Noh, Y., and Dudhia, J.: A New Vertical Diffusion Package with an Explicit Treatment of Entrainment Processes, Mon. Weather Rev., 134, 2318-2341, https://doi.org/10.1175/15200493(2004)132<0519:EFOWPU>2.0.CO;2, 2006.

Hong, S.-Y.: A new stable boundary-layer mixing scheme and its impact on the simulated East Asian summer monsoon, Q. J. Roy. Meteor. Soc., 136, 1481-1496, https://doi.org/10.1002/qj.665, 2010.

Kamm, S., Möhler, O., Naumann, K.-H., Saathoff, H., and Schurath, U.: The heterogeneous reaction of ozone with soot aerosol, Atmos. Environ., 33, 4651-4661, https://doi.org/10.1016/S13522310(99)00235-6, 1999.

Kane, R.: Is ozone depletion really recovering?, J. Atmos. Sol.-Terr. Phy., 70, 1455-1459, https://doi.org/10.1016/j.jastp.2008.04.012, 2008.

Kane, R.: Ozone depletion, worst not yet over, Indian J. Radio Space Phys., 38, 313-316, 2009.

Klekociuk, A. R., Brown, P. G., Pack, D. W., ReVelle, D. O., Edwards, W. N., Spalding, R. E., Tagliaferri, E., Yoo, B. B., and Zagari, J.: Meteoritic dust from the atmospheric disintegration of a large meteoroid, Nature, 436, 1132-1135, https://doi.org/10.1038/nature03881, 2005.

Kompalli, S., Babu, S. S., Bharatan, L. N., and Moorthy, K. K.: Spring-time enhancement in aerosol burden over a high-altitude location in western trans-Himalaya: results from long-term observations, Curr. Sci. India, 111, 117-131, https://doi.org/10.18520/cs/v111/i1/117-131, 2016.

Kremser, S., Thomason, L. W., von Hobe, M., Hermann, M., Deshler, T., Timmreck, C., Toohey, M., Stenke, A., Schwarz, J. P., Weigel, R., Fueglistaler, S., Prata, F. J., Vernier, J.-P., Schlager, H., Barnes, J. E., Antuña-Marrero, J.-C., Fairlie, D., Palm, M., Mahieu, E., Notholt, J., Rex, M., Bingen, C., Vanhellemont, F., Bourassa, A., Plane, J. M. C., Klocke, D., Carn, S. A., Clarisse, L., Trickl, T., Neely, R., James, A. D., Rieger, L., Wilson, J. C., and Meland, B.: Stratospheric aerosol-Observations, processes, and impact on climate, Rev. Geophys., 54, 278-335, https://doi.org/10.1002/2015RG000511, 2016.

Kuhlbusch, T. A. J., Andreae, M. O., Cachier, H., Goldammer, J. G., Lacaux, J.-P., Shea, R., and Crutzen, P. J.: Black carbon formation by savanna fires: Measurements and implications for the global carbon cycle, J. Geophys. Res.-Atmos., 101, 2365123665, https://doi.org/10.1029/95JD02199, 1996. 
Kumar, R., Barth, M. C., Pfister, G. G., Nair, V. S., Ghude, S. D., and Ojha, N.: What controls the seasonal cycle of black carbon aerosols in India?, J. Geophys. Res.-Atmos., 120, 7788-7812, https://doi.org/10.1002/2015JD023298, 2015.

Kwan, I. and Rutherford, D.: Transatlantic airline fuel efficiency ranking, 2014, The International Council on Clean Transportation, http://www.theicct.org/transatlantic-airline-efficiency-2014 (last access: 8 August 2017), 2015.

Lamarque, J.-F., Bond, T. C., Eyring, V., Granier, C., Heil, A., Klimont, Z., Lee, D., Liousse, C., Mieville, A., Owen, B., Schultz, M. G., Shindell, D., Smith, S. J., Stehfest, E., Van Aardenne, J., Cooper, O. R., Kainuma, M., Mahowald, N., McConnell, J. R., Naik, V., Riahi, K., and van Vuuren, D. P.: Historical (1850-2000) gridded anthropogenic and biomass burning emissions of reactive gases and aerosols: methodology and application, Atmos. Chem. Phys., 10, 7017-7039, https://doi.org/10.5194/acp-10-7017-2010, 2010.

Lau, K., Kim, M., and Kim, K.: Asian summer monsoon anomalies induced by aerosol direct forcing: the role of the Tibetan Plateau, Clim. Dynam., 26, 855-864, https://doi.org/10.1007/s00382006-0114-z, 2006.

Lau, W. K. M., Kim, M.-K., Kim, K.-M., and Lee, W.-S.: Enhanced surface warming and accelerated snow melt in the Himalayas and Tibetan Plateau induced by absorbing aerosols, Environ. Res. Lett., 5, 025204, http://stacks.iop.org/1748-9326/5/i=2/a= 025204 (last access: 8 August 2017), 2010.

Liou, K.-N.: An introduction to atmospheric radiation, Academic press, vol. 84, 2002.

Mackinnon, I. D. R., McKay, D. S., Nace, G., and Isaacs, A. M.: Classification of the Johnson Space Center stratospheric dust collection, J. Geophys. Res.-Solid, 87, A413-A421, https://doi.org/10.1029/JB087iS01p0A413, 1982.

Meenu, S., Rajeev, K., Parameswaran, K., and Nair, A. K. M.: Regional distribution of deep clouds and cloud top altitudes over the Indian subcontinent and the surrounding oceans, J. Geophys. Res.-Atmos., 115, D05205, https://doi.org/10.1029/2009JD011802, 2010.

Mlawer, E. J., Taubman, S. J., Brown, P. D., Iacono, M. J., and Clough, S. A.: Radiative transfer for inhomogeneous atmospheres: RRTM, a validated correlated-k model for the longwave, J. Geophys. Res.-Atmos., 102, 16663-16682, https://doi.org/10.1029/97JD00237, 1997.

Moorthy, K. K., Babu, S. S., Sunilkumar, S. V., Gupta, P. K., and Gera, B. S.: Altitude profiles of aerosol BC, derived from aircraft measurements over an inland urban location in India, Geophys. Res. Lett., 31, L22103, https://doi.org/10.1029/2004GL021336, 2004.

Nair, V., Babu, S. S., Moorthy, K. K., Sharma, A., Marinoni, A., and Ajai: Black carbon aerosols over the Himalayas: direct and surface albedo forcing, Tellus B, 65, 19738, https://doi.org/10.3402/tellusb.v65i0.19738, 2013.

Nair, V. S., Babu, S. S., Gogoi, M. M., and Moorthy, K. K.: Largescale enhancement in aerosol absorption in the lower free troposphere over continental India during spring, Geophys. Res. Lett., 43, 11453-11461, https://doi.org/10.1002/2016GL070669, 2016.

Okada, K., Ikegami, M., Uchino, O., Nikaidou, Y., Zaizen, Y., Tsutsumi, Y., and Makino, Y.: Extremely high proportions of soot par- ticles in the upper troposphere over Japan, Geophys. Res. Lett., 19, 921-924, https://doi.org/10.1029/92GL00487, 1992.

Olivier, J. G. J., Bouwman, A., Berdowski, J., Veldt, C., Bloos, J., Visschedijk, A., Zandveld, P., Haverlag, J. L.: Description of EDGAR Version 2.0: A set of global emission inventories of greenhouse gases and ozone-depleting substances for all anthropogenic and most natural sources on a per country basis and on 1 degree $x 1$ degree grid, Rijksinstituut voor Volksgezondheid en Milieu RIVM, 1996.

Onasch, T. B., Jayne, J. T., Herndon, S., Worsnop, D. R., MiakeLye, R. C., Mortimer, I. P., and Anderson, B. E.: Chemical Properties of Aircraft Engine Particulate Exhaust Emissions, J. Propul. Power, 25, 1121-1137, https://doi.org/10.2514/1.36371, 2009.

Outcalt, S., Laesecke, A., and Freund, M. B.: Density and Speed of Sound Measurements of Jet A and S-8 Aviation Turbine Fuels, Energ. Fuel., 23, 1626-1633, https://doi.org/10.1021/ef800888q, 2009.

Paraschis, Y. and Gittens, A.: Annual Report 2013, The Voice of the World's Airports, Airports Council International, http://www.aci. aero/Publications/Full-Publications-Listing (last access: $8 \mathrm{Au}-$ gust 2017), 2014.

Petzold, A. and Schönlinner, M.: Multi-angle absorption photometry - a new method for the measurement of aerosol light absorption and atmospheric black carbon, J. Aerosol Sci., 35, 421-441, https://doi.org//10.1016/j.jaerosci.2003.09.005, 2004.

Petzold, A., Ogren, J. A., Fiebig, M., Laj, P., Li, S.-M., Baltensperger, U., Holzer-Popp, T., Kinne, S., Pappalardo, G., Sugimoto, N., Wehrli, C., Wiedensohler, A., and Zhang, X.-Y.: Recommendations for reporting "black carbon" measurements, Atmos. Chem. Phys., 13, 8365-8379, https://doi.org/10.5194/acp13-8365-2013, 2013.

Piccolo, F. and Gittens, A.: Annual Report 2014, The Voice of the World's Airports, Airports Council International, http://www.aci. aero/Publications/Full-Publications-Listing (last access: $8 \mathrm{Au}-$ gust 2017), 2015.

Piccolo, F. and Gittens, A.: Annual Report 2015, The Voice of the World's Airports, Airports Council International, http://www.aci. aero/Publications/Full-Publications-Listing (last access: $8 \mathrm{Au}-$ gust 2017), 2016.

Prijith, S., Babu, S. S., Lakshmi, N., Satheesh, S., and Moorthy, K. K.: Meridional gradients in aerosol vertical distribution over Indian Mainland: Observations and model simulations, Atmos. Environ. Pt. B, 125, 337-345, https://doi.org/10.1016/j.atmosenv.2015.10.066, 2016.

Pusechel, R. F., Blake, D. F., Snetsinger, K. G., Hansen, A. D. A., Verma, S., and Kato, K.: Black carbon (soot) aerosol in the lower stratosphere and upper troposphere, Geophys. Res. Lett., 19, 1659-1662, https://doi.org/10.1029/92GL01801, 1992.

Pueschel, R. F., Boering, K. A., Verma, S., Howard, S. D., Ferry, G. V., Goodman, J., Allen, D. A., and Hamill, P.: Soot aerosol in the lower stratosphere: Pole-to-pole variability and contributions by aircraft, J. Geophys. Res.-Atmos., 102, 13113-13118, https://doi.org/10.1029/96JD03061, 1997.

Qian, Y., Flanner, M. G., Leung, L. R., and Wang, W.: Sensitivity studies on the impacts of Tibetan Plateau snowpack pollution on the Asian hydrological cycle and monsoon climate, Atmos. Chem. Phys., 11, 1929-1948, https://doi.org/10.5194/acp11-1929-2011,, 2011. 
Ramanathan, V. and Carmichael, G.: Global and regional climate changes due to black carbon, Nat. Geosci., 1, 221-227, https://doi.org/10.1038/ngeo156, 2008.

Ramanathan, V., Chung, C., Kim, D., Bettge, T., Buja, L., Kiehl, J., Washington, W., Fu, Q., Sikka, D., and Wild, M.: Atmospheric brown clouds: Impacts on South Asian climate and hydrological cycle, P. Natl. Acad. Sci. USA, 102, 5326-5333, https://doi.org/10.1073/pnas.0500656102, 2005.

Ramanathan, V., Ramana, M. V., Roberts, G., Kim, D., Corrigan, C., Chung, C., and Winker, D.: Warming trends in Asia amplified by brown cloud solar absorption, Nature, 448, 575-578, https://doi.org/10.1038/nature06019, 2007.

Randel, W. J., Park, M., Emmons, L., Kinnison, D., Bernath, P., Walker, K. A., Boone, C., and Pumphrey, H.: Asian Monsoon Transport of Pollution to the Stratosphere, Science, 328, 611613, https://doi.org/10.1126/science.1182274, 2010.

Rao, T., Uma, K. N., Narayana Rao, D., and Fukao, S.: Understanding the transportation process of tropospheric air entering the stratosphere from direct vertical air motion measurements over Gadanki and Kototabang, Geophys. Res. Lett., 35, L15805, https://doi.org/10.1029/2008GL034220, 2008.

Ricchiazzi, P., Yang, S., Gautier, C., and Sowle, D.: SBDART: A Research and Teaching Software Tool for Plane-Parallel Radiative Transfer in the Earth's Atmosphere, Bull. Am. Meteorol. Soc., 79, 2101-2114, https://doi.org/10.1175/15200477(1998)079<2101:SARATS>2.0.CO;2, 1998.

Satheesh, S. and Moorthy, K. K.: Radiative effects of natural aerosols: A review, Atmos. Environ., 39, 2089-2110, https://doi.org/10.1016/j.atmosenv.2004.12.029, 2005.

Satheesh, S. and Ramanathan, V.: Large differences in tropical aerosol forcing at the top of the atmosphere and Earth's surface, Nature, 405, 60-63, https://doi.org/10.1038/35011039, 2000.

Satheesh, S., Moorthy, K. K., and Srinivasan, J.: New Directions: Elevated layers of anthropogenic aerosols aggravate stratospheric ozone loss?, Atmos. Environ., 79, 879-882, https://doi.org/10.1016/j.atmosenv.2013.07.052, 2013.

Satheesh, S. K., Vinoj, V., and Moorthy, K. K.: Vertical distribution of aerosols over an urban continental site in India inferred using a micro pulse lidar, Geophys. Res. Lett., 33, L20816, https://doi.org/10.1029/2006GL027729, 2006.

Satheesh, S. K., Moorthy, K. K., Babu, S. S., Vinoj, V., and Dutt, C. B. S.: Climate implications of large warming by elevated aerosol over India, Geophys. Res. Lett., 35, L19809, https://doi.org/10.1029/2008GL034944, 2008.

Schultz, M., Backman, L., Balkanski, Y., Bjoerndalsaeter, S., Brand, R., Burrows, J., Dalsoeren, S., de Vasconcelos, M., Grodtmann, B., Hauglustaine, D., Heil, A., Hoelzemann, J., Isaksen, I., Kaurola, J., Knorr, W., Ladstaetter-Weißenmayer, A., Mota, B., Oom, D., Pacyna, J., Panasiuk, D., Pereira, J., Pulles, T., Pyle, J., Rast, S., Richter, A., Savage, N., Schnadt, C., Schulz, M., Spessa, A., Staehelin J., Sundet, J., Szopa, S., Thonicke, K., van het Bolscher, M., van Noije, T., van Velthoven, P., Vik, A, and Wittrock, F.: REanalysis of the TROpospheric chemical composition over the past 40 years (RETRO)-A long-term global modeling study of tropospheric chemistry, Final Report, Jülich/Hamburg, Germany, 2007.

Schurath, U. and Naumann, K.: Heterogeneous processes involving atmospheric particulate matter, Pure Appl. Chem., 70, 13531361, https://doi.org/10.1351/pac199870071353, 1998
Schwarz, J. P., Gao, R. S., Fahey, D. W., Thomson, D. S., Watts, L. A., Wilson, J. C., Reeves, J. M., Darbeheshti, M., Baumgardner, D. G., Kok, G. L., Chung, S. H., Schulz, M., Hendricks, J., Lauer, A., Kärcher, B., Slowik, J. G., Rosenlof, K. H., Thompson, T. L., Langford, A. O., Loewenstein, M., and Aikin, K. C.: Single-particle measurements of midlatitude black carbon and light-scattering aerosols from the boundary layer to the lower stratosphere, J. Geophys. Res.-Atmos., 111, D16207, https://doi.org/10.1029/2006JD007076, 2006.

Sheridan, P. J., Brock, C. A., and Wilson, J. C.: Aerosol particles in the upper troposphere and lower stratosphere: Elemental composition and morphology of individual particles in northern midlatitudes, Geophys. Res. Lett., 21, 2587-2590, https://doi.org/10.1029/94GL01387, 1994.

Sheridan, P. J., Arnott, W. P., Ogren, J. A., Andrews, E., Atkinson, D. B., Covert, D. S., Moosmüller, H., Petzold, A., Schmid, B., Strawa, A. W., Varma, R., and Virkkula, A.: The Reno Aerosol Optics Study: An Evaluation of Aerosol Absorption Measurement Methods, Aerosol Sci. Tech., 39, 1-16, https://doi.org/10.1080/027868290901891, 2005.

Smirnova, T. G., Brown, J. M., and Benjamin, S. G.: Performance of Different Soil Model Configurations in Simulating Ground Surface Temperature and Surface Fluxes, Mon. Weather Rev., 125, 1870-1884, 1997.

Smirnova, T. G., Brown, J. M., Benjamin, S. G., and Kim, D.: Parameterization of cold-season processes in the MAPS landsurface scheme, J. Geophys. Res.-Atmos., 105, 4077-4086, https://doi.org/10.1029/1999JD901047, 2000.

Snetsinger, K. G., Ferry, G. V., Russell, P. B., Pueschel, R. F., Oberbeck, V. R., Hayes, D. M., and Fong, W.: Effects of El Chichón on stratospheric aerosols late 1982 to early 1984, J. Geophys. Res.-Atmos., 92, 14761-14771, https://doi.org/10.1029/JD092iD12p14761, 1987.

Stettler, M., Eastham, S., and Barrett, S.: Air quality and public health impacts of $\{\mathrm{UK}\}$ airports, Part I: Emissions, Atmos. Environ., 45, 5415-5424, https://doi.org/10.1016/j.atmosenv.2011.07.012, 2011.

Stettler, M. E. J., Boies, A. M., Petzold, A., and Barrett, S. R. H.: Global Civil Aviation Black Carbon Emissions, Environ. Sci Technol. 47, 10397-10404, https://doi.org/10.1021/es401356v, 2013.

Strawa, A. W., Drdla, K., Ferry, G. V., Verma, S., Pueschel, R. F., Yasuda, M., Salawitch, R. J., Gao, R. S., Howard, S. D., Bui, P. T., Loewenstein, M., Elkins, J. W., Perkins, K. K., and Cohen, R.: Carbonaceous aerosol (soot) measured in the lower stratosphere during POLARIS and its role in stratospheric photochemistry, J. Geophys. Res.-Atmos., 104, 26753-26766, https://doi.org/10.1029/1999JD900453, 1999.

Sunilkumar, S. V., Babu, A., and Parameswaran, K.: Mean structure of the tropical tropopause and its variability over the Indian longitude sector, Clim. Dynam., 40, 1125-1140, https://doi.org/10.1007/s00382-012-1496-8, 2013.

Thampi, B. V., Parameswaran, K., and Sunilkumar, S.: Semitransparent cirrus clouds in the upper troposphere and their contribution to the particulate scattering in the tropical $\{$ UTLS\} region, J. Atmos. Sol.-Terr. Phy., 74, 1-10, https://doi.org/10.1016/j.jastp.2011.09.005, 2012.

Thompson, G., Rasmussen, R. M., and Manning, K.: Explicit forecasts of winter precipitation using an improved bulk micro- 
physics scheme, Part I: Description and sensitivity analysis, Mon. Weather Rev., 132, 519-542, https://doi.org/10.1175/15200493(2004)132<0519:EFOWPU>2.0.CO;2, 2004.

Timko, M. T., Onasch, T. B., Northway, M. J., Jayne, J. T., Canagaratna, M. R., Herndon, S. C., Wood, E. C., MiakeLye, R. C., and Knighton, W. B.: Gas Turbine Engine Emissions - Part II: Chemical Properties of Particulate 061505, https://doi.org/10.1115/1.4000132, 2010.

Turco, R. P., Toon, O. B., Hamill, P., and Whitten, R. C.: Effects of meteoric debris on stratospheric aerosols and gases, J. Geophys. Res.-Ocean., 86, 1113-1128, https://doi.org/10.1029/JC086iC02p01113, 1981.

Uma, K. N., Kumar, K. K., Shankar Das, S., Rao, T. N., and Satyanarayana, T. M.: On the Vertical Distribution of Mean Vertical Velocities in the Convective Regions during the Wet and Dry Spells of the Monsoon over Gadanki, Mon. Weather Rev., 140, 398-410, https://doi.org/10.1175/MWR-D-11-00044.1, 2012.

Vernier, J.-P., Thomason, L. W., and Kar, J.: CALIPSO detection of an Asian tropopause aerosol layer, Geophys. Res. Lett., 38, L07804, https://doi.org/10.1029/2010GL046614, 2011.
Weingartner, E., Saathoff, H., Schnaiter, M., Streit, N., Bitnar, B., and Baltensperger, U.: Absorption of light by soot particles: determination of the absorption coefficient by means of aethalometers, J. Aerosol Sci., 34, 1445-1463, https://doi.org/10.1016/S0021-8502(03)00359-8, 2003.

Wiedinmyer, C., Akagi, S. K., Yokelson, R. J., Emmons, L. K., AlSaadi, J. A., Orlando, J. J., and Soja, A. J.: The Fire INventory from NCAR (FINN): a high resolution global model to estimate the emissions from open burning, Geosci. Model Dev., 4, 625641, https://doi.org/10.5194/gmd-4-625-2011, 2011.

Wild, O., Zhu, X., and Prather, M.: Fast-J: Accurate Simulation of In- and Below-Cloud Photolysis in Tropospheric Chemical Models, J. Atmos. Chem., 37, 245-282, https://doi.org/10.1023/A:1006415919030, 2000.

Yasunari, T. J., Bonasoni, P., Laj, P., Fujita, K., Vuillermoz, E., Marinoni, A., Cristofanelli, P., Duchi, R., Tartari, G., and Lau, K.-M.: Estimated impact of black carbon deposition during premonsoon season from Nepal Climate Observatory - Pyramid data and snow albedo changes over Himalayan glaciers, Atmos. Chem. Phys., 10, 6603-6615, https://doi.org/10.5194/acp10-6603-2010, 2010. 